\title{
Social Capital and the Formal Legal System: Evidence from Prefecture-Level Data in Japan
}

\section{Citation}

J. Mark Ramseyer, Social Capital and the Formal Legal System: Evidence from Prefecture-Level Data in Japan (Harvard John M. Olin Discussion Paper Series Discussion Paper No. 767, Apr. 2014).

\section{Published Version}

http://www.law.harvard.edu/programs/olin_center/papers/pdf/Ramseyer_767.pdf

\section{Permanent link}

http://nrs.harvard.edu/urn-3:HUL.InstRepos:20200198

\section{Terms of Use}

This article was downloaded from Harvard University's DASH repository, and is made available under the terms and conditions applicable to Other Posted Material, as set forth at http:// nrs.harvard.edu/urn-3:HUL.InstRepos:dash.current.terms-of-use\#LAA

\section{Share Your Story}

The Harvard community has made this article openly available.

Please share how this access benefits you. Submit a story.

Accessibility 


\section{HARVARD}

JOHN M. OLIN CENTER FOR LAW, ECONOMICS, AND BUSINESS

SOCIAL CAPITAL AND THE FORMAL LEGAL SYSTEM: EVIDENCE FROM PREFECTURE-LEVEL DATA IN JAPAN

J. Mark Ramseyer

Discussion Paper No. 767

$04 / 2014$

Harvard Law School

Cambridge, MA 02138

This paper can be downloaded without charge from:

The Harvard John M. Olin Discussion Paper Series:

http://www.law.harvard.edu/programs/olin_center/

The Social Science Research Network Electronic Paper Collection: http://ssrn.com/abstract=2425763

This paper is also a discussion paper of the John M. Olin Center's Program on Corporate Governance. 
J. Mark Ramseyer

Professor, Harvard Law School

Visiting Professor, University of Tokyo Law Faculty

Comments welcomed: ramseyer@law.harvard.edu

\title{
Social Capital and the Formal Legal System: Evidence from Prefecture-Level Data in Japan
}

\author{
By J. Mark Ramseyer*
}

\begin{abstract}
Verifiable proxies for social capital potentially provide an empirically tractable way to identify environments where social norms both constrain behavior and substitute for judicial enforcement. Using regression and factor analysis with Japanese prefecture-level data, I explore several aspects of this possibility. First, I find that people in prefectures with high levels of social capital more readily comply with a range of low-level legal mandates. Second, reflecting the fact that social norms need not point toward government-approved ends, taxpayers in high social-capital prefectures (particularly in the agricultural sector) are more -- not less -- likely to evade taxes.

Third, conditional on levels of economic welfare, I find that: (a) firms in prefectures with low levels of social capital are more likely to default on their contracts; (b) residents in low social-capital prefectures are probably (the results are ambiguous) more likely to litigate; (c) creditors of distressed debtors in low socialcapital prefectures are more likely to apply in court for enforcement orders, and (d) distressed debtors in low social-capital prefectures are more likely to file in court for bankruptcy protection.
\end{abstract}

* Mitsubishi Professor of Japanese Legal Studies, Harvard Law School; Visiting Professor, University of Tokyo Faculty of Law. I received helpful comments and suggestions from Robert Gibbons, John Haley, Masaaki Iwasaki, Paul Lagunes, Salil Mehra, Curtis Milhaupt, Gregory Noble, and Frances Rosenbluth, and workshop participants at Columbia University, Hitotsubashi University, Nishimura \& Asahi, and the University of Tokyo. 
New York diamond merchants make agreements orally, and keep them. They promise to perform, as Lisa Bernstein (1992) famously explained, and trust each other to perform. They perform and trust because they live their lives within densely overlapping networks of social and religious ties. They perform and trust because they live within a community with an extraordinary level of social capital.

Farmers in Shasta County, California, do much the same. They too structure their contracts and resolve their disputes privately, reported Robert Ellickson (1986, 1991). What is more, they structure and negotiate with scarcely a thought for the law. Again, they do this because of the dense social networks -- the high levels of social capital -- within which they live and work.

Long-distance merchants in the medieval Mediterranean world cut their contracts beyond the reach of any formal court system as well, wrote Avner Greif (1993). They could do this because they kept their transactions within the closed world of Maghribi Jewish circles. They trusted and performed despite the long distances and the absence of any formal enforcement mechanism because of social capital -- because they shared a panoply of closely overlapping ties.

If some people keep their promises, others cheat routinely. Given the resulting risks, in parts of the modern world people negotiate large-stakes agreements only where they can enforce any ensuing claims in court. Bernstein, Ellickson, and Greif detail polar cases where people trust each other without judicial access. Other scholars focus on the other extreme -- a post-apocalyptic cross between Camus'

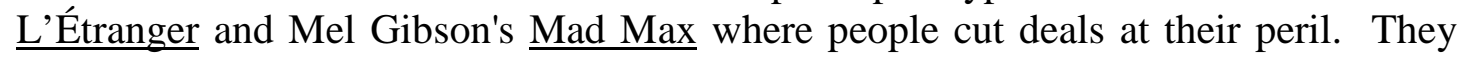
rely on each other only when they can turn to an authoritarian court to enforce any deal they might make.

Between these extremes, people sometimes perform and sometimes renege. They sometimes trust and sometimes suspect. They sometimes invoke the courts, and sometimes manage their transactions and disputes without them. In the article that follows, I locate prefecture-level data on social capital in modern Japan. With that data, I explore possible determinants of trust and performance in this intermediate (neither Jewish diamond merchants, nor anomic anonymity) world. Between the extremes of rigid honesty and ruthless opportunism, I ask whether levels of social capital mirror legal compliance and contractual performance. Note that I do not demonstrate causation: I lack a mechanism by which to identify causation. Instead, I simply measure basic patterns of correlation.

The evidence is mixed. In societies with high levels of social capital, people comply with legal mandates that they support and cheat on those they dispute. In high social-capital communities, they obey their traffic rules, make their pension contributions, and pay their TV broadcast fees. Particularly in the most heavily agricultural prefectures, however, they cheat on taxes when they can. The phenomenon suggests a simple "everyone's doing it" dynamic -- or, as a popular modern haiku in Japan puts it:

Red traffic light;

if we all cross together,

no one is afraid."

Conditional on levels of economic welfare, firms in prefectures with low levels of social capital more often turn insolvent and default on their promises. When 
a dispute does ensue, people in low social-capital prefectures probably (the evidence is ambiguous) more often sue. Creditors more often apply in court for enforcement orders, and debtors more often file in court for bankruptcy protection. Parties are also more likely to use the courts in prefectures with more lawyers. Note that these results on the use of legal strategies are robust to instrumental variable estimates using levels of social capital from the 1920s.

I begin by reviewing the empirical literature on social capital (Sec. I). The concept began in sociology, but owes much of its current prominence to political scientist Robert Putnam. I canvass the resulting scholarship, and identify multiple proxies for levels of social capital in modern Japan (Sec. II). Through factor analysis, I use the prefecture-level proxies to create synthetic measures that approximate social capital as an unobserved latent variable (Sec. III). I then regress measures of legal compliance (Sec. IV), contractual performance, and contract enforcement (Sec. V) on the synthetic factor variables. I close by suggesting two alternative mechanisms for these empirical results (Sec. VI).

\section{Litigation and Social Capital}

A. Introduction:

Robert Putnam (1995, 2000) hit a chord when he suggested nearly two decades ago that the modern American malaise might stem from a decline in "social capital." Sociologists replied by noting antecedents in their own discipline. They pointed to the concept in Durkheim and Marx (Portes, 1998: 2). They cited more recent discussions by James Coleman $(1988,1990)$ and Pierre Bourdieu (1985).

But it was Putnam who brought the theme home. It was he who introduced it to political science, to economics, and to the chattering classes more generally. As Putnam articulated the idea, people invest in social capital within their communities by building, maintaining, and strengthening their ties with each other. They help the PTA. They join the Rotary Club. They coach soccer leagues. They attend churches and synagogues.

In the course of doing all this, Putnam's citizens created social capital: the byzantine network of reciprocal favors and obligations that let them overcome the collective-action problems that would otherwise plague their communities. With social capital intact, they volunteer. They help strangers. They deter petty crime. And together, they build the basis for participatory democracy.

More recently and controversially, Charles Murray (2012) contested any notion that American social capital has declined across the board. It remains intact in professional communities, he argued, even as it has vanished from among the working class. He calls the former "Belmont," after the affluent Boston suburb, and the latter "Fishtown," after the blue-collar Philadelphia neighborhood of that name. In America's Belmonts, social capital remains high -- and people read the newspaper, vote, attend church, volunteer at schools, marry, bear children within marriage, and stay married. In its Fishtowns, social capital has disappeared. With social capital high, in Belmont people keep their promises; with that capital gone, in Fishtown they rely on neighbors at their peril. In Belmont, people trust; in Fishtown, they cheat.

Build ties, and people behave. Integrate themselves into large and crosscutting social networks, as Saegert \& Winkel (2004: 220) put it, and they come to "share a sense of mutual obligation, shared norms, and trustworthiness." Make friends, and "[i]nformation flows freely and from multiple channels." Convey that information, and people know what they need to know to punish those who 
misbehave: "norms of behavior are reinforced in many settings and sanctions for violating these norms can be effectively brought to bear."

Coleman (1988, 1990) gave the classic statement of social capital. As he articulated the concept, residents can enforce their communal norms only if they keep a network of overlapping ties dense enough to create "closure" (Coleman, 1988: S105-07):

Norms arise as attempts to limit negative external effects [by some members] or to encourage positive ones. But, in many social structures where these conditions exist, norms do not come into existence. The reason is what can be described as lack of closure of the social structure.

Posit two societies, explained Coleman (id.). In one, members maintain ties with other members that do not intertwine. A knows B and C, but B and C do not know each other and neither do they know anyone else in common. Without such mutual connections, they find it harder to punish people who violate important norms:

In an open structure ..., actor A, having relations with actors B and C, can carry out actions that impose negative externalities on B or $\mathrm{C}$ or both. Since they have no relations with one another, but with others instead (D and $\mathrm{E}$ ), they cannot combine forces to sanction $\mathrm{A}$ in order to constrain the actions. Unless either B or $\mathrm{C}$ alone is sufficiently harmed and sufficiently powerful vis-a-vis A to sanction alone, A's actions can continue unabated.

If members do maintain intertwined ties, the society is "closed." Should anyone deviate from the norms, many in the network will know, and many can punish (Coleman, id.). "In a structure with closure," Coleman continued, "B and C can combine to provide a collective sanction, or either can reward the other for sanctioning A."

The apparent American decline in social capital mattered to Putnam, because he thought the capital key to democratic governance. In northern Italy, he noted, residents maintained a more vibrant democratic order than in the south. They maintained it through (Putnam's first canonical example) the vast number of choral societies they joined. In the 1950s U.S., residents maintained their democratic order through (to use his second canonical example) the bowling leagues they joined. By the 21st century, they bowled alone.

\section{B. Methodological Choices:}

1. Individual and group attributes. -- In the years since Putnam posited his decline in American social capital, scholars have worked hard to transform the concept into empirically tractable form. The econometric problems alone are formidable, as Durlauf (2002) describes in detail. But scholars remain divided over even so basic a question as whether to measure social capital at the individual or community level.

Individuals create social capital by choice. As Portes (1998: 4) put it, "the acquisition of social capital requires deliberate investment of both economic and cultural resources," and people make those investments individually. Glaeser, et al. (2002) construct (and test) models of investment in social capital by rational individuals. And Durlauf (2002: F468-69) notes that treating the concept as a community-level aggregate aggravates already-troubling econometric dilemmas.

Yet the concept itself of social capital describes communities. When Putnam writes about Italy and the U.S., he compares the density of social networks both across space and across time -- but within communities. To be sure, explain Saegert \& Winkel (2004: 220), social capital "can derive from a variety of individual actions, 
motivations, and expectations and can be used for individual as well as collective benefit." But at root (id.), it "is a property of groups." Stolle \& Rochon (1998: 50) write more bluntly: "to refer to an individual's social capital" is "a category mistake."

2. Survey data and behavioral evidence. -- Scholars also vary in the evidence they use to measure that social capital. Putnam examined behavior: he studied voting patterns and newspaper circulation, and famously counted the associations people joined -- not just choral societies and bowling leagues, but groups like the PTA, churches and Lion's Clubs as well. Murray examined behavior too: he looked to divorce, illegitimacy, crime, and (again) associational membership.

Other scholars use survey data. To the extent social capital benefits people, it does so in part by letting them "trust" each other. Rather than rely on behavioral proxies like voter turnout rates or choral groups, some scholars (including Helliwell \& Putnam, 2007) measure trust directly. Toward that end, they use survey questions that address this generalized sense of trust (Stolle \& Rochon, 1998; Knack 2002, 2002b; Knack \& Keefer, 1997; Paxton, 1999).

Yet survey data necessarily raise questions about how accurately they measure the underlying phenomenon. When Glaeser, et al. (2000: 833) compare experimental evidence of trust and trustworthiness against standard survey questions, they find the latter egregiously unreliable. Bowles \& Gintis (2002: F421) forthrightly declare that they "doubt that the commonly used survey instruments are reliable predictors of actual behaviours."

3. Independent and dependent variables. -- Scholars also differ in the use to which they put social capital: some ask how social capital affects other phenomena, while others ask which phenomena create social capital. Some place it on the right side of the equation, while others place it on the left. Putnam famously does both -he uses social capital as both an independent variable and the dependent. The more thriving associational tradition in northern Italy, he first argued, led to a better functioning democracy than in the south (social capital as an independent variable). The longer hours spent watching television in the modern U.S., he now claims, has caused levels of social capital to fall (as a dependent variable).

Scholars pursue both directions. Many treat social capital as an independent variable. To list just a few of the studies, Knack \& Keefer (1997) ask whether widespread membership in groups correlates positively with improved economic performance, and find that it does not; Knack (2002) asks whether it correlates positively with better government, and finds that it does not; Rice \& Sumberg (1997) ask whether civic engagement correlates positively with government performance, and find that it does; and Skinner \& Staeger (2007) ask whether social capital correlates with technological diffusion, and find that it does. Others treat social capital as the dependent variable. Again, to take a few of the many examples, Paxton (1999) uses historical data to explore the ways in which social capital is (or is not) declining in the U.S.; Alesina \& La Ferrara (2000) ask what effect economic inequality and ethnic fragmentation have on social capital.

4. Univariate and factor analyses. -- In running regressions on social capital (whether on the left or on the right), most scholars proxy for the concept with a single variable. Some run univariate regressions. Some use a single proxy for social capital, but run multi-variate regressions that hold constant other sources of variation. And 
those who do collect multiple proxies for the concept generally run a series of regressions, one proxy at a time (e.g., Knack, 2002).

Given the nature of social capital as an unobserved latent variable, scholars rely on single proxies at their peril. As Paxton (1999: 90) put it, the "problem with previous assessments of social capital is that they rely on single indicators." Social capital, he continued, "is a general concept." One "should not expect that it can be captured with just one variable." To address exactly this problem, Putnam urges a broad approach (Putnam, 2000, 414; orig. in ital.):

No single source of data is flawless, but the more numerous and diverse the sources, the less likely that they could all be influenced by the same flaw. Two independent (though necessarily imperfect) strands of evidence are better than one, and more than two are better still, especially if they have different imperfections.

Once a scholar locates multiple proxies, given their colinearity he will need to combine them into a single measure. For this task, psychologists and sociologists typically propose factor analysis. The exercise models the observed proxies as linear combinations of an unobserved latent variable, and then estimates its parameters. Skinner \& Staiger (2007) take this approach, as do Paxton (1999), Sabatini (2009) and Ramseyer (2014).

5. Anti-social outcomes. -- Social capital contributes to Coleman's "closure," and "closed" communities exhibit the intertwined social ties by which members enforce collective norms. In Bowling Alone, Putnam argued that communities with high levels of that capital promote participatory democracy. Elsewhere, he wrote that "communities endowed with a diverse stock of social networks and civic associations are in a stronger position to confront poverty and vulnerability, resolve disputes, and take advantage of new opportunities" (Putnam \& Goss, 2004).

This is all a bit ingenuous, of course. Communities enforce a wide variety of norms, and not all of them promote democracy. Much less do communities necessarily confront poverty, shield the vulnerable, or exploit new opportunities. In the 1930s, choral-society-rich northern Italy turned fascist (Riley, 2005; Chambers \& Kopstein, 2001). When the Soviet empire collapsed, Serbs embedded in dense networks of social ties massacred their Bosnian Croat and Muslim neighbors (Chambers \& Kopstein, 2001: 842).

By far the most telling example, however, involves the Nazis. Through historical narrative, Berman (1997: 402) shows "how a robust civil society actually helped scuttle the twentieth century's most critical democratic experiment, Weimar Germany." The "high levels of association," explains she (id.), "served to fragment rather than unite German society."

Satyanath, Voiglaender \& Voth (2013) make the same point econometrically. From city directories, they calculate the density of civil associations (not just political associations, but "bowling, singing, hiking, and animal breeding clubs"; id., 3) in Weimar Germany. With that density, they then predict the speed at which the Nazi Party grew. The denser the associational networks, the faster the spread of Nazism. Conclude Satyanath, et al. (2013: 3), "the Nazi Party spread more rapidly in the fabric of German society where citizens had more points of contact outside the workplace."

As a result, that social capital can facilitate anti-social outcomes is no longer news (e.g., Chambers \& Kopstein, 2001; Knack, 2002b; Portes, 1998; Acemoglu, et al., 2012). Perhaps, Putnam suggests, scholars should distinguish associations that "bridge" different groups, from associations that merely "bond" together people 
already in a group. Several scholars have followed that distinction (e.g., Stolle \& Rochon, 1998: 57; Knack, 2002; Knack \& Keefer, 1997). Within the debate over the Nazi rise, for example, Berman (1997) finds the distinction helpful: bonding associations facilitated the Nazi rise in Germany, but bridging groups did not. Satyanath, et al. (2013) disagree: bonding and bridging associations both contributed to Nazi growth.

\section{Social Capital and Law:}

1. Introduction. -- All this matters to legal studies, because it potentially gives an empirically tractable way to determine when people use the formal legal apparatus -- to determine which communities can enforce norms and resolve disputes without invoking the courts. Students of social capital routinely argue that it facilitates the negotiation of transactions, and smooths the resolution of disputes. Where social capital is high, people trust each other to cooperate and keep their word (Annen, 2003). They rely on social pressure to enforce their agreements. Only when social capital falls do they turn to the law. Unable anymore to enforce their agreements informally, they hire lawyers and use the courts.

Where social capital is high people cooperate, in short, and where it is low they sue. Lieberman $(1983,186)$ put the claimed tie between social capital and litigation most starkly:

Litigiousness is not a legal but a social phenomenon. It is born of a breakdown in community, a breakdown that exacerbates and is exacerbated by the growth of law. ... [U]ntil there is a consensus on fundamental principles, the trust that is essential to a self-ordering community cannot be.

Putnam (2000) explained the tie between social capital and litigation as a function of the trust that comes from a dense network of social ties. "[F]ormal contracts, courts, litigation, adjudication, and enforcement by the state" are, he writes (id., 144-145), "one alternative to generalized reciprocity and socially embedded honesty." When trust is high, Knack \& Keefer (1997: 1253) suggest, people are "less dependent on formal institutions to enforce agreements" and can make do without "government-backed property rights or contract enforcement."

2. Law and social norms. -- Over the course of the 1990s, legal scholars largely ignored the debate over "social capital," and developed a parallel corpus on "social norms" instead (see the synthesis by E. Posner, 1998, 2002). They focused -at the obvious risk of over-simplification -- on several points. First, as Ellickson (1998, 546; 1990; 1986) put it, they found "informal systems of control" to be "especially" important "where interacting parties have a continuing relationship" at stake. The more stable a population, the more secure its norms and mechanisms of social control.

Second, legal scholars concluded that people follow communal norms in order to to retain the chance to trade. Should anyone try to deviate, others enforce the norms by threatening a boycott. They mandate behavior, explained Richard Posner (1997: 366), by tying their norms to an "implicit threat of ostracism, that is, of refusal of advantageous transactions" (see also R. Posner \& Rasmusen, 1999; R. Posner, 1998, 554; Akerlof, 1976, 1980). The fewer the transactions among members in the group, the less secure the norms. 
Third, scholars found that communication matters. "Norms and rules, whether publicly or privately created, embody and convey information," explained Katz (1996: 1749):

They cannot be followed unless information is transmitted regarding their substantive content; they cannot be enforced unless information is transmitted regarding who has obeyed them, who has violated them, and who is to impose any associated punishment or reward.

The more people gossip, the more information they collect. The better their information, the more they know about their neighbors. And the more closely they follow what their neighbors do, the more secure their collective norms (see Akerlof, 1976; Ellickson, 1990: 180-81).

3. Law in discrete communities. Within this literature on social norms, three closely focused studies of discrete groups took on unusual prominence. Each examined a small, insular world where members seemed able to enforce norms and resolve disputes without the courts. Lisa Bernstein (1992) studied the Jewish diamond merchants in New York. She found that they deliberately shifted their highest-stake transactions outside the ambit of the U.S. legal system (id.: 133). Within "the diamond industry, extralegal contracts are the dominant contractual paradigm," wrote Bernstein. Rather than turn to the courts, merchants construct a market where "enforcement depends on social ostracism or reputational damage" (id., 133).

Robert Ellickson (1986, 1991) identified much the same phenomenon among the farmers and cattle ranchers of Shasta County, California. As the cattle roamed, they damaged fences and ate crops. For the most part, residents settled their resulting disputes without going to court, and without even following the rules a court would enforce. They interacted with each other repeatedly, and across a wide range of issues. Because they thought their norms better suited to their micro-economy than California property or tort law, they "discourage[d] members from taking intermember disputes into the legal system" (id., 1991: 250).

Finally, Avner Greif (1993) examined long-distance commerce among 11thcentury Maghribi Jewish traders in the Muslim Mediterranean world. Greif did formally what Bernstein and Ellickson did informally: he modeled the ties among traders and agents as an indefinitely repeated game. He then examined the historical record, and found that the members of the community did indeed share information with each other, and enforce honesty by punishing violators mutually and multilaterally. They used, he explained, a "multilateral punishment strategy."

4. Social norms and social capital. -- The empirical studies in social capital suggest an approach to a problem that the literature on "law and social norms" posed but never resolved: finding an empirically tractable way to identify the communities where members enforce norms and resolve disputes outside of the formal legal regime. Within that literature on norms, the theory was clear enough: norms matter most where people interact with each other regularly and extensively, and plan to continue doing so indefinitely. Unfortunately, other than polar cases, scholars never identified -- tractably, empirically -- the communities with the most effective informal mechanisms.

The three famous micro-studies represent the polar cases. Bernstein's diamond merchants formed a tightly knit and largely closed religious minority. 
Ellickson's Shasta county farmers and ranchers were born into the community and expected to die within it. Greif's Maghribi traders comprised a tightly knit, closed religious society where each member could count on the others to punish a cheating agent.

Each of the three studies captured a world where members followed norms -and although none of the three focused on the term, each also captured a world with extremely high levels of social capital. Each constituted a world with Coleman's "closure": a network of overlapping, intertwined social connections where information travelled extensively and members collectively enforced expectations of proper behavior on each other. Greif's "multilateral punishment strategy" is nothing if not Coleman's "closure," and Bernstein's diamond traders appear and reappear in the subsequent literature as the archetypal high social-capital community (e.g., Portes, 1998: 6, 15; Paxton, 1999: 93; Coleman, 1988: S98).

What social scientists have developed in the two decades since the three studies is way potentially to identify empirically the communities most likely to enforce "social norms" -- and most likely to enforce them without recourse to the judiciary. By operationalizing social capital, they may have created an empirically tractable way to distinguish when people will follow social norms and when they will not; when they will structure their transactions through the formal legal apparatus and when they will not; and when they will use the courts to resolve their disputes and when they will not.

5. The Japanese promise. Japanese data let scholars explore this connection between quantifiable social capital and the formal legal system in a world where the quality of that legal system does not vary. When people informally enforce norms and resolve disputes, they do so in part to save time and money. Compared to informal mechanisms, formal contracts and lawsuits usually take time and cost money. But the formal and informal sectors can vary on other dimensions too. The village elder who mediates a local dispute can be wise or foolish, honest or corrupt. And so too the local judge in the formal sector: judges can be predictable or haphazard, smart or dumb, fast or slow, a paragon of integrity or a simple cheat.

As a result, when people choose between formal and informal sectors, they consider not just the effectiveness of the informal sector but the quality of formal mechanisms as well. All else equal, they may prefer informal processes for the time and money saved, but all else is not necessarily equal. From jurisdiction to jurisdiction, statutes differ, procedures differ, judges differ. Courts vary not just in the time and cost they entail, but in the clarity, honestly, and predictability they offer as well.

American court quality varies in ways that often are hard to measure. In part, the variation reflects differences among state court systems. Scholars can measure state court congestion, but they will find it harder to rank the quality of a state's common law or the efficiency of its court procedures. Harder still will they find it to measure a judge's intelligence, diligence, and honesty. Even federal courts vary in quality. Presidents appoint these men and women for life -- to specific courts. Over time, some federal courts will acquire more judges with talent than others. Some will develop a more sensible common law than others. None of this will be easy to gauge empirically.

By contrast, Japan offers a relentlessly uniform legal system (Ramseyer, 1994; Ramseyer \& Rasmusen, 2001, 2003). All law is national: local governments do not pass statutes. All fora are national: prefectures do not run courts. And no judges are 
local: the government does not appoint judges to specific courts. Instead -- and in part precisely to maintain uniform quality -- the court rotates its judges regularly across the country. Generally on three-year cycles, it moves its judges from court to court, city to city. Cities and prefectures do not acquire a distinctive jurisprudence. Neither do they acquire a distinctive judicial quality.

\section{This Project:}

1. The variables. -- In the article that follows, I use evidence from Japan to explore the correlation between (i) levels of social capital in a community, and (ii) the frequency with which its members comply with legal mandates and invoke the legal system. I treat social capital as an attribute of the community rather than of individuals, and measure its level at the 47 Japanese prefectures. I would have preferred data from a more local level. Unfortunately, most of the variables I use are not measured below the prefectural level. The limited number of observations obviously restricts the reliability of the results. I also would have preferred data on change over time. Unfortunately again, several of the variables are not measured on a regular basis.

I identify 11 proxies for social capital. In this effort, I locate primarily behavioral measures rather than attitudinal survey evidence. Some of the variables I use "cause" social capital, while others represent its "effect" (Paxton, 1999: 101). Given that I focus on the correlation between levels of social capital and the manipulation of formal legal institutions, I use both types of variables without distinguishing between the two.

Although these 11 proxies cover a wide range of phenomena, they correlate with each other closely. Of the 55 possible pairs among them, the correlation is statistically significant at the 10 percent level in 44 . Apparently, most of the variables capture the same basic pattern of inter-prefectural variation.

2. Synthetic factors. -- Because of the empirical problems involved in using 11 highly correlated variables, I combine them through factor analysis. Rather than enter proxies for social capital in regressions independently, in other words, I reduce them to two synthetic measures of the unobserved latent variable, social capital. I then use the resulting synthetic measures as the independent variables.

I construct similar synthetic measures for economic and educational levels. Both economic welfare and education correlate heavily with social capital, but they also affect the use of the formal legal system independently of any effect through social capital. In order to examine the effect of economic welfare and educational investments independent of social capital more generally, I retain them as distinct variables.

3. Regressions. Finally, I regress several measures of the role of the legal system (of the extent people comply with legal mandates, of the extent they manipulate the judicial system) on these economic, educational, and social capital factors. As appropriate, I add the number of attorneys per capita. Given that attorneys choose to locate where people use the courts, I instrument the number of attorneys and use two-stage least squares.

In their regression of Nazi growth rates on German social capital, Satyanath, et al. (2013) suggest that their results could reflect omitted variable bias: people joined the Nazi party where "economic distress was high," and given their low opportunity cost also spent more time in clubs. They address the possible problem by 
using two-stage least squares with measures of associational density from the 19th century. Although I include measures of economic welfare and educational levels in my regressions, I could face a similar problem: omitted variables reflecting the contemporary environment could potentially affect the use of the legal system. "To separate the deeper historical roots" of social capital (as Satyanath, et al., 2012 put it), I add two-stage least squares estimates with instruments for levels of social capital in the 1920s.

Note that this study -- at its root, and like most other studies of social capital -demonstrates correlation rather than causation. This is not a project where identification lets us tease out causal effect. Satyanath, et al., find that the spread of Nazi party correlated with social capital levels. The logic for the mechanism by which social ties contributed to the spread of the party is there, but the study fundamentally remains a study in correlation. Similarly, Skinner \& Staiger (2007) find that technological adoption correlates with levels of social capital. Again, the logic for for the phenomenon is there, but the project itself remains a project in correlation.

II. Variables

A. Introduction:

I focus on three sets of questions. First, do levels of social capital correlate with legal compliance? Where social capital is high, do people more willingly do what the law tells them to do? Are they more likely to pay their taxes?

Second, do levels of social capital correlate with contractual performance? Where social capital is high, do people more willingly keep their promises?

Last, do levels of social capital correlate with judicial enforcement? Where social capital is high, do people less often use the courts to enforce their contracts? Are firms less likely to manipulate the law to avoid liability?

To explore these issues, I construct the following variables. I describe the dependent variables in Section B, and the proxies for economic welfare, educational investment, and levels of social capital in Section C. I explain the additional independent variables in Section D, and the instruments used in the two-stage estimates in Section E. I include selected summary statistics in Table 1.

[Insert Table 1 about here.]

\section{B. Dependent Variables:}

1. Compliance with low-level mandates. -- In societies bound together by high levels of social capital, people more readily comply with norms of appropriate behavior. If (i) those norms support a given government mandate, and (ii) the government does not enforce compliance with the mandate through the courts, then compliance should correlate positively with levels of social capital. Consider first three low-level mandates that enjoy widespread support, and which the government primarily enforces through social norms.

(Traffic violations)/roads: Number of traffic violations in 2008 (Japan Now, 2014), divided by the number of kilometers of roads in 2013 (Somu sho, 2014).

NHK payment rate: Percent of households paying their mandated levy to the national broadcasting network (the NHK) in 2011 (NHK, 2012). 
Pension contribution rate: Percent of person-months of mandated national pension contributions for the self-employed for the 2011 fiscal year that were actually paid by the end of May 2013 (Kosei rodo sho, 2013).

2. Tax evasion. -- Government data do not directly disclose tax compliance rates. After all, the divergence between true income and reported income is information private to the taxpayer. Neither need the level of prosecution reflect compliance rates. After all, potentially it could reflect instead prosecutorial resources, and those resources could reflect local electoral dynamics. Accordingly, I estimate the level of tax evasion by dividing tax revenues by prefectural GDP. I calculate three separate measures.

(Self-reported personal tax)/GDP: Amount of personal income tax (shotoku zei) paid on income reported on returns in 2011, in billion yen (Kokuzei cho, 2011: 68), divided by 2010 GDP in million yen (Naikaku fu, 2013).

(Total personal tax)/GDP: Total amount of personal income tax, whether paid on income reported on returns or withheld from income at source, in billion yen (Kokuzei cho, 2011), divided by 2010 GDP in million yen (Naikaku fu, 2013).

(Corporate tax)/(Non-agricultural GDP): Amount of corporate tax (hojin zei) paid in 2011, in billion yen (Kokuzei cho, 2011: 213), divided by 2010 non-agricultural GDP in million yen (Naikaku fu, 2013).

3. Contractual performance. -- To estimate the extent to which people keep their promises in business, I measure the rate at which firms default on their notes.

Insolvency PC: Companies facing economic insolvency (tosan; defined as firms that default on two notes within six months) in 2010, per capita. I take the number of insolvencies from the credit-rating firm, Tokyo shoko risaachi (2013).

4. Legal manipulation. -- To capture how readily residents manipulate the formal legal apparatus, I measure the willingness of creditors to file enforcement actions against insolvent (or nearly insolvent) debtors, and the willingness of those debtors to file for bankruptcy protection.

Lawsuits PC: Total civil suits filed in 2010, per capita (Saiko, 2011: tab. 4).

Enforcement PC: Enforcement petitions (kyosei shikko; both realty and personalty) in 2010, per capita (Saiko, 2011: tab. 4).

Bankruptcy PC: Petitions for bankruptcy (hasan) protection in 2010, per capita (Saiko, 2011: tab. 4).

C. Proxy Variables: 
prefecture:

1. Economic. -- I define four proxies for the level of economic welfare in a

Income PC: Income in 2010 per capita, from Naikaku fu (2013).

Savings PC: Mean bank deposits (but not other wealth) per capita in 2004, in 1000 yen, from Somu (2004).

Foreign auto fraction: Percentage of all cars in 2009 made by foreign firms, from Todo-ran (2013a). Foreign cars in Japan are disproportionately luxury models.

2. Educational. -- I include seven proxies for the level of investments in education:

Advance to high school: The percentage of middle school (grades 79) students in 2002 who advanced to high school (grades 10-12) (Toba, 2005: 89). Education in Japan is compulsory only through grade 9.

Expenses per student, elementary: The mean amount spent on each elementary-school student in 2008, in 1,000 yen (Monbu sho, 2008).

Expenses per student, middle: The mean amount spent on each middle-school student in 2008, in 1,000 yen (Monbu sho, 2008).

Expenses per student, high: The mean amount spent on each highschool student in 2008, in 1,000 yen (Monbu sho, 2008).

Standardized test, mean: 2013 mean score in the Japanese language and mathematics standardized tests in public schools for sixth and ninth grades (Todo-ran, 2013b)

Standardized test, middle school: 2013 mean score in the Japanese language and mathematics standardized tests in public schools for ninth-grade students (Todo-ran, 2013c). The ninth-grade scores are said to reflect home environments more fully than sixth grade scores (Todo-ran, 2013c).

Truancy rate: Percentage of middle school students missing 30 or more days per year (Todo-ran, 2013d).

3. Social capital. --

a. Civic engagement. I use voter turnout rates as a straightforward measure of civic engagement: how many people take part in elections? To capture the extent to which people participate more broadly in their community, I examine volunteering rates.

Voter turnout: Voter turnout rates for the national election in 2003 (Somu sho, 2003). 
Volunteering: Percentage of residents 15 years or older performing volunteer work, 2006 (Somu sho, 2006).

b. Social cohesion. To measure social cohesion, I examine investments in community centers, participation in religious groups, and local patterns of crime. First, I use staffing patterns at community centers as a measure of local willingness to invest in the facilities and staffing necessary to build community cohesion. Second, I use religious participation as an index of social involvement. According to Putnam (2000: 67), religious participation functions "as a powerful correlate of most forms of civic engagement"; according to Murray (2012: 207), it constitutes "one of the key sources of social capital in a community." Third, I add the rate of serious crime as a further measure of social cohesion. As Putnam (2000: 308) put it:

Higher levels of social capital, all else being equal, translate into lower levels of crime. ... States with more social capital have proportionately fewer murders. ... This inverse relationship is astonishingly strong -- as close to perfect as one might find between any two social phenomena.

Community center staff, PC: The number of staff at local community centers (kominkan) in 2005, per capita (Monbu sho, 2005).

Religious followers, PC: The number of members of a religious organization (of any faith) in 2008, per capita (Bunka cho, 2008).

Crime rate: The number of violations of the Criminal Code (excluding traffic violations) in 2010, per 1,000 population (Homu sho, 2011).

c. Workplace ties. Putnam (2000: 87-88) observes that "[m]any people form rewarding friendships at work," and "feel a sense of community among co-workers, and enjoy norms of mutual help and reciprocity on the job." As a result, those with low job tenure enjoy less "trust and social connectedness in the workplace." Those who lose work completely withdraw psychologically from the community itself. The financial stress from their unemployment places "a profoundly depressing effect on social involvement" (Putnam, 2000: 192-193), and leads to "less time spent with friends, ... less frequent attendance at church, less volunteering, and less interest in politics." Because educated men and women contribute disproportionately to a community's stock of social capital, the job prospects for the best-educated youth matter particularly heavily for a community's ability to cohere as an integrated unit.

Job tenure: Average number of years on a job, 2009 (Gekkyu, 2009).

Unemployment rate: Unemployment rate in 2010 (Somu sho, 2012).

Unemployment, college graduates: Unemployment rate among new college graduates, 2002 (Toba, 2005: 75).

d. Family cohesion. To measure family cohesion, I take divorce rates, divorce settlement rates, and illegitimacy rates. First, the divorce rate straightforwardly measures that cohesion. Second (and more indirectly), the divorce settlement rate measures that cohesion as well. Because Japanese couples more readily divorce in prefectures with low levels of social capital, the marriages that do 
end in divorce in high-social-capital prefectures are more bitter. Consequently, couples find it harder to settle their divorces out-of-court (Ramseyer, 2014).

Third, illegitimacy rates directly measure how closely couples tie childbirth to marriage. Within the modern U.S., children born out of marriages (born "illegitimate") do not fare well. As Murray $(2012,164)$ put it, their mothers "come disproportionately from the lower socioeconomic classes and they tend to provide worse environments for raising children than married mothers." What is more, if mothers are bearing their children outside of marriage, then families are necessarily playing a smaller role in the community -- yet "families with children are the core" of well-functioning communities (Murray, 2012, 165). If illegitimacy is high, social capital is low.

Divorce rate: The number of divorces in 2010, divided by the number of marriages in 2010 (Kosei: 2010a).

Divorce settlement rate: The number of divorces negotiated out of court (kyogi), divided by the total number of divorces (Kosei: 2010a).

Illegitimacy rate: Percentage of children born outside of marriage, 2010 (calculated from data available at Kosei, 2010a).

D. Other Independent Variables:

I add the following variables as appropriate.

GDP growth, 2005-10: Fractional growth in GDP, 2005-2010, from Naikaku fu (2013).

Small \& medium enterprises PC: The number of small and mediumsized enterprises (as defined by the Ministry of Economy \& Industry), divided by the 2010 population (Chusho, 2011: tab. 2). ${ }^{1}$

Agriculture PC: The percentage of the population engaged in agriculture, given by the Ministry of Agriculture, Forestry and Fisheries (Todo-ran, 2013e).

LDP support rate: The percentage of support for the long-time governing, modestly right-of-center Liberal Democratic Party, in the July 2010 upper house election, as reflected in the proportional-representation section of the election (Todo-ran, 2013f).

Attorneys PC: The number of attorneys per capita, 2010 (Nihon bengoshi, 2011: 84-85).

E. Instruments:

I use the following instruments in the two-stage analyses.

\footnotetext{
${ }^{1}$ A small- or medium-sized enterprise is any firm with 300 or fewer regular empoyees (100 for firms in wholesale or service industries, 50 for retail or restaurant firms), or any firm with 300 million yen or less in capital (100 million for firms in a wholesale industry, 50 million for firms in retail, restraurant, or service industries).
} 


\section{For attorneys.}

Scriveners PC: The number of judicial scriveners (shiho shoshi) per capita, 2012 (Nihon shiho, 2012).

\section{Historical instruments.}

Divorce rate, 1925: The number of divorces in 1925, divided by the number of marriages in 1925 (Naikaku, 1926).

Illegitimacy rate, 1925: Percentage of children born outside of marriage, 1925 (Naikaku, 1926).

Young wife rate, 1925: Fraction of brides aged 17 or younger, 1925 (Naikaku, 1926).

Elementary school attendance, 1925: The percentage of children of elementary school age attending school, 1925 (Monbu sho, 1926).

Emigrants, 1899-1941 PC: The number of residents emigrating to other countries, 1899-1941, per capita (population 1940) (Kokusai, 1991).

Tenancy rate, 1923: The fraction of irrigated rice paddies cultivated by tenants in 1923 (Kawagoe, 1995).

Tenant riots, 1912-26 PC: Number of tenant riots during the Taisho period (1912-26), per capita (population 1929) (Aoki, 1972).

Prostitute birthplace, 1924 PC: Number of 1924 licensed Tokyo prostitutes (shogi) born in the prefecture, per capita (population 1925) (Fukumi, 1928).

Geisha birthplace, 1924 PC: Number of 1924 Tokyo geisha born in the prefecture, per capita (population 1925) (Fukumi, 1928).

Barmaid birthplace, 1926 PC: Number of 1926 Tokyo and Osaka barmaids born in the prefecture, per capita (population 1925) (Fukumi, 1928).

Infant mortality sex ratio, 1925: Deaths of boys relative to girls, under age 1 for 1925 (Naikaku, 1926).

III. Synthetic Factors

A. The Project:

Rather than regress the dependent variables directly on the several proxies for social capital, I use the proxies to estimate the underlying level of social capital itself. This is the procedure used in Skinner \& Staiger (2007), Paxton (1999), Sabatini (2009) and Ramseyer (2014). As in other studies on this topic, social capital here constitutes an unmeasured latent variable. Through factor analysis I combine its various proxies into a synthetic variable that more closely approximates it. \& As Stata $(2005,213)$ put it: 
[The procedure] reduces the number of variables in an analysis by describing linear combinations of the variables that contain most of the information and ... admit meaningful interpretations.

More colloquially, Skinner \& Staiger (2007: 552) write that the "factor model assumes that all of the state-level variables are linear combinations of a few unobserved factors ..., plus an independent error ...." I use the standard "principal factors" estimation procedure, with "orthogonal varimax" rotation. Following general practice, I retain those factors with eigenvalues greater than 1 . Table 2 reports the rotations.

[Insert Table 2 about here.]

I begin by using the three proxies for economic welfare to estimate a common economic factor. As the rotated factor loadings in Panel A shows, the resulting factor loads all three proxies heavily. What is more, all three rise with the level of economic welfare: The economic factor used in this study correlates positively with the level of economic welfare.

I use the seven proxies for levels of educational investment to estimate a second set of factors. The eigenvalue cutoff of 1 generates two education factors. The first heavily loads the standardized exam variables, and produces a synthetic measure that rises with the level of educational achievement. The second loads proxies related to educational expenditures. This variable rises with the level of educational investment as well. As a result, both variables are positively correlated with the level of education in the prefecture (Panel B).

Finally, in Panel C, I use the 11 proxies for social capital to calculate synthetic factors that reflect the level of that capital. Again, the eigenvalue cutoff generates two variables. Note that the first variable heavily loads the divorce, divorce settlement, unemployment, and illegitimacy variables to produce a factor that falls with levels of social capital (Panel C). The second factor loads the voter turnout, volunteering, community center, and crime variables to produce a variable that rises with levels of social capital. The result is a pair of variables that moves in opposite directions: factor 1 declines with the level of social capital in a community, and factor 2 increases.

\section{B. The Result:}

Given that the economic factor loads heavily per capita income and bank accounts, it assigns the lowest score to the very poor southern island of Okinawa. The other four lowest scores fall to three rural prefectures in the northeast (Iwate, Aomori and Akita) and one on the southern island of Kyushu (Kagoshima). The factor assigns the highest score to Tokyo, and the four other highest scores to the adjacent prefecture of Kanagawa (site of Yokohama city), and three western prefectures (Aichi [site of Nagoya city], and Shiga and Fukui [both near Kyoto]).

The first education factor correlates strongly with the economic factor, and Okinawa scores low by this measure as well. Recall that the factor loads heavily standardized test scores. Osaka also scores low but the other low scores fall to rural provincial areas like Kochi (on Shikoku island), Oita (on Kyushu), and the far northern island of Hokkaido. Tokyo has the 11th highest score.

The second education factor loads heavily educational expenses. Tokyo again scores high by this measure. Other high scoring prefectures, however, include the rural areas of Kochi, Shimane, Akita and Iwate. The urban areas in the west (Osaka, Aichi) and near Tokyo (Saitama, Kanagawa) score very low. 
The first social capital factor loads measures of family cohesion and employment, and falls with social capital. It correlates inversely with the economic and first education factors, and assigns Okinawa the highest score (the lowest social capital). Other high-scoring prefectures (low social capital) include the southern prefectures of Miyazaki (on Kyushu) and Kochi (on Shikoku), and the northern prefectures of Hokkaido and Aomori. The lowest score (high social capital) goes to Niigata, a rice-producing prefecture on the Japan Sea coast. Tokyo is the 11th lowest prefecture.

The second social capital factor loads heavily measures of civil engagement and crime, and rises with social capital. It correlates positively with the two education factors and negatively with the economic factor. Okinawa scores low by this measure, but so do urban areas like Tokyo, Osaka, Aichi, and Kyoto. Rural prefectures like Shimane, Tottori, Iwate, Yamagata and Ishikawa score high.

\section{Legal Compliance}

A. The Ambiguity:

Ask, then, when firms will comply with government-imposed requirements -and when they will not. If levels of social capital are high, people find themselves more closely tied to networks within their communities. Their relations are "closed," as Coleman put it, and they will (so sociological theory asserts) more willingly comply with communal norms.

All else equal, the correlation between levels of social-capital and rates of legal compliance should turn on at least two considerations. First, it should depend on the extent to which the (distant) government enforces requirements that mirror (local) social values. Those local values could point in many directions. In pre-war Germany, the Nazi party grew fastest where the social capital was densest. Fascists grew fastest in northern Italy with its dense capital networks. Depending on the dominant political preferences in the community, local norms could push members to comply with government mandates, or push them away. If legal compliance reflects widely held (local) values, the density of social capital should correlate positively with compliance; if instead those values instead suggest non-compliance, social capital should correlate negatively.

Second, the observed effect of social capital should turn on the extent to which the government enforces its mandates through formal legal mechanisms. Suppose that a government mandate reflects local social values. If the government does not try to enforce those mandates through the legal (particularly criminal) process, then social capital should indeed correlate positively with observed compliance rates.

If the government actively enforces the mandates through the formal process, however, then its efforts may crowd out the effect of social norms. After all, data only show correlation when they vary. To the extent that formal enforcement causes people everywhere to comply, that observed variation will disappear.

\section{B. The Project:}

1. Low-level mandates. -- Consider first three relatively low-level government mandates. These mandates involve rules that enjoy relatively widespread support, and which the government rarely enforces through formal judicial mechanisms.

(a) Public broadcasting fees. Take the subscription fee to the national television and radio broadcasting network, the NHK. The network is reasonably 
popular, but all Japanese households with a television set must pay the fee whether they like the programs or not. Even for freely available broadcasts, the amount is non-trivial: in late 2013, 13,600 yen/month.

Some Japanese resent paying the NHK fee. After all, popular as the broadcasts may be, not all Japanese like them. Much of the music is classical, and although NHK news broadcasts tend to be unbiased, they also tend to be boring. Bloggers on internet sites swap strategies about how to skirt the fee. NHK still collects the money through door-to-door solicitation agents, so bloggers discuss how to avoid paying them. When the NHK agent appears at the door, some Japanese pretend not to be home. If they answer the door, some claim not to own a television. If they admit to owning a set, some simply refuse to pay anyway.

Compliance is widespread, but not complete. As of 2011, 72.5 percent of Japanese households paid the fee (NHK, 2012). The government does not bring criminal prosecutions against those who refuse, but it has started to file a small number of civil suits. According to the Yomiuri newspaper, one court in 2013 did order a non-compliant person to pay the fee -- but it added that the case was only the 6th civil suit ever for non-payment (Yomiuri, 2013).

(b) National pension contributions. Second, consider the Japanese government's pay-as-you-go pension system. The system actually includes two distinct networks. The first covers employees. Given that employers withhold the premiums (which vary by income) from a worker's paycheck, compliance is high.

The second pension network covers the self-employed and several other groups (see generally Iwasaki, 2004). Participation is mandatory, but people must take the initiative to pay the fees. Despite a legal requirement that everyone participate, the government does not punish those who shirk. As of March 2013, the premium was a flat 14,980 yen/month. If a worker paid the premiums for 40 years, he would upon retirement receive an annual pension of 786,500 yen (Nihon, 2013: 1). In 2012, the self-employed pension network included 18.6 million people (MHLW, 2012: 1). Of that group, the government had granted a full hardship exemption to 2.4 million (MHLW, 2012: 1).

On a widespread scale, self-employed Japanese avoid payment. After 15,000 yen per month for 40 years, a 790,000 yen pension is a very bad deal. Japanese recognize the "badness" of the deal, and often try to avoid it. In early 2003, journalists found even many prominent national politicians who skipped their required contributions. Voters hounded several of them from office (Onishi, 2004), but the government does not itself penalize those who shirk their contributions. In 1990, compliance (calculated by paid month-premiums/payable month-premiums) had been 85.2 percent. By 2012, it had fallen to 58.6 percent (MHLW, 2012: 3).

(c) Traffic violations. Last, take the willingness of drivers to flout traffic rules. The penalties are modest, and enforcement (other than for exceptions like DUI or reckless driving) is modest. Most violations, of course, impose no substantial dangers either on the driver or on other parties. Instead, the cost of flouting traffic rules turns on the corrosive effect on traffic norms more generally -- corrosion that leads eventually to violations that do impose social costs.

Traffic violation rates in Japan vary significantly. The rates are typically highest in urban centers. By violations per capita, annual rates ranged from .033 in the prefecture of Wakayama to .103 in Yamaguchi (Tokyo was third, at .087). By violations per automobile, they ranged from .043 in Ibaragi to .253 in Tokyo. By 
violations per kilometer of roads, they ranged from 1.7 in Akita (2.5 in Wakayama, 1.9 in Ibaragi) to 46.5 in Tokyo.

2. Tax compliance. -- The tax mandate involves much higher stakes. Japan maintains a graduated personal income tax. The rates rise to 40 percent on all income beyond 18 million yen. With high top rates, the incentives to cheat are high as well.

Although taxpayers may have reason to cheat, most lack much opportunity. Only 6 million file returns (Kokuzei, 2011: 58). The rest satisfy their liability through taxes withheld at source -- 54 million had taxes withheld by their employers on wages (Kokuzei, 2011: 197). Unlike in the U.S., the tax laws in Japan set deduction and credit amounts at levels that do not apply to most taxpayers. As a result, most taxpayers have no obligation to file returns, and most do not.

The self-employed are another matter, of course. Given that they do not earn wages subject to withholding, they file returns. Necessarily, they have substantial opportunity to understate income and exaggerate expenses. And among the selfemployed, farmers (according to popular wisdom) are particularly egregious tax cheats.

For corporations, the tax rate is 38 percent. Among small firms, compliance (again according to popular wisdom) is low. These small firms produce about half of the Japanese GDP. Headquartered locally, they file their tax returns locally. Large firms produce and sell around the country, but typically maintain headquarters in Tokyo. Given that home office, they also file their tax returns in Tokyo.

The tax system does not enjoy broad support. Although Japanese voters value the perquisites their government provides (highways, schools, sanitation), many consider it too large and wasteful, and their tax rates too high. About its decision to raise the consumption tax rate from 5 to 8 percent, for example, 74 percent of respondents in one poll opposed the change (Diamond, 2013; see Noble, 2014).

C. The Results:

1. Introduction. -- Regressions of rates of compliance with the three low-level government mandates indicate that cooperation rises with levels of social capital. Regressions of rates of compliance with the tax law, however, suggest the exact opposite.

2. Modest mandates. --

(a) Public broadcasting fee. For example, consider the NHK broadcast fees. First, according to the regressions reported in the first column of Table 3, people are more likely to pay the fee in educated communities. The coefficient on the first educational factor is positive and statistically significant. The coefficient on the second is insignificant. The insignificance is a function of including the other factors in the regression. In a simple pairwise correlation, the correlation between the second educational factor and the payment rate is positive and significant at the 10 percent level.

[Insert Table 3 about here.]

Second, people are also more likely to pay the fees in communities with high levels of social capital. Recall that the first social capital factor falls with levels of social capital while the second rises with social capital. The coefficient on the first factor is negative and strongly significant; the coefficient on the second is positive and strongly significant. 
Last, holding educational and social capital levels constant, the coefficient on the economic factor is significantly negative -- payment rates fall rather than rise with income. This is, however, an artifact of holding the other factors constant. In a simple pairwise correlation between the economic factor and the payment rate, the relation is not significant.

(b) Pension payment. Turn to the second column of Table 3: contributions toward the national pension system. The results closely resemble the results on the NHK broadcast fees. First, the payment contribution rate rises with education. The coefficient on both educational factors is positive, and the coefficient on the second factor is significantly so.

Second, the contribution rate rises with levels of social capital. Again, recall that the two factors point in opposite directions. The coefficient on the first social capital factor is negative, and the coefficient on the second factor is positive: the contribution rate rises with social capital levels. Both coefficients are statistically extremely significant.

Last, the coefficient on the economic factor is insignificant. This relation is also insignificant in a simple pairwise correlation.

(c) Traffic violations. Last, consider the relation between social capital and traffic violation rates. As reported in the third column of Table 3, traffic violations rates are similarly strongly related to levels of social capital. The coefficient on the first social capital factor is positive, and the coefficient on the second negative. The former is statistically strongly significant. Recall that it falls with levels of social capital: the higher the levels of social capital, the lower the rates of traffic violations.

Traffic violation rates are not related to educational levels. The coefficient on the economic factor is significantly positive: the wealthier the prefecture, the higher the rate of traffic violations. This is, however, an artifact of the very wealthy but very congested Tokyo. Drop Tokyo, and the coefficient on the economic factor becomes insignificant. The coefficient on the first social capital factor remains positive and strongly significant.

3. Tax mandates. -- The Japanese tax system does not enjoy wide scale support. Many Japanese think the rates too high, and the government too large and inefficient. To examine the extent to which they nonetheless comply with the tax requirement, I divide tax revenues by GDP. Recall that most Japanese do not file returns -- they satisfy their liability through withholding, and do not qualify for deductions or credits. To focus on taxes paid by those who file returns, in Panel A of Table 4, I use the calculated factors to predict the ratio of (i) tax revenues from selfreported personal income to (ii) prefectural GDP. Because prefectures may vary in the fraction of taxpayers who file returns (generally, the self-employed), in Panel B I predict the ratio of (i) all (self-reported and withheld-at-source) personal tax revenues to (ii) prefectural GDP. In Table 5, I predict the ratio of corporate tax revenues to prefectural GDP.

(a) Personal tax. I take as the dependent variable in Table 4, Panel A, the ratio of self-reported personal tax revenues to prefectural GDP. Initially (see first column), note that the amount of taxes paid as a fraction of prefectural GDP falls with the level of social capital. This holds true for both measures of social capital. The coefficient on the first factor (which falls with social capital) is positive but not significant: the 
higher the level of social capital, the lower the amount of taxes paid. The coefficient on the second factor (which rises with social capital) is significantly negative: the higher the level of social capital, the lower the tax revenue on self-reported income.

[Insert Table 4 about here.]

The phenomenon suggests the same moral ambiguity about social capital as the studies of Nazi Germany. The tighter the inter-linked bonds in a society, the more closely its members will follow social norms. In pre-war Germany, those bonds led many Germans to join the Nazi party. In modern Japan, they apparently lead many Japanese to avoid the personal income tax. They will pay the subscription fee to the national broadcasting network. They will pay their premia to the national pension system. They will follow traffic rules. But the personal income tax they apparently avoid if they can.

In the second column, I add the fraction of the population in agriculture. Note the result: the coefficient on the agricultural rate is negative and significant, and the coefficient on the second social capital factor falls by half. It remains significant, but only at the 10 percent level. Farmers often live in communities with dense networks of inter-laced social ties, of course. They live in communities with high levels of social capital -- indeed, the correlation coefficient between the agricultural rate and the second social capital factor is 0.75 , significant at more than the 0.1 percent level. Farmers resent the national tax, and -- by popular wisdom -- cheat massively. According to the regression in the second column, they do indeed. Much of the negative effect of social capital in the first column apparently reflects the tax evasion in agricultural communities.

In the third column, I ask whether political affiliation might affect the propensity of residents to evade taxes. If it does, no evidence of the phenomenon appears in the regression.

In Panel B, I take as the dependent variable the ratio of all personal tax revenues to prefectural GDP. Prefectures vary in the fraction of residents who are self-employed. Necessarily, they also vary in the fraction who file returns -- the ratio of (i) self-reported tax revenues to (ii) total tax revenues is lowest in Tokyo and Osaka. It is highest in Okinawa. To compensate for this variation, in Panel B I add to the tax on self-reported income the tax withheld at source.

The results in Panel B are largely unchanged. The coefficient on the first social capital factor (which falls with social capital) is significant and positive, while the coefficient on the second factor (which rises with social capital) is significant and negative: levels of economic welfare and educational investment held constant, the higher the level of social capital, the lower the ratio of taxes to GDP. The coefficient on agriculture is significantly negative as well: again, economic and educational factors held constant, the greater the percentage of the population in agriculture, the lower the ratio of taxes to GDP.

(b) Corporate tax. The same inverse correlation between social capital and tax revenues appears with respect to corporate taxes. Such is the message of the first column of Table 5, where I regress the ratio of corporate taxes to prefectural GDP. Note two preliminary qualifications. First, rather than total GDP I divide tax revenues by non-agricultural GDP. Farmers in Japan operate primarily in noncorporate form. Their revenues would thus be subject to the personal tax but not a corporate tax. Accordingly, I deduct from the GDP used in the denominator the amount of prefectural GDP attributable to agriculture.

[Insert Table 5 about here.] 
Second, I omit Tokyo. Large firms operate nationally but file their tax returns out of their headquarters in Tokyo. Taxes paid in Tokyo will thus include large amounts earned through facilities located elsewhere. Accordingly, I omit Tokyo from the dataset. For comparative purposes, however, I add back Tokyo in the fourth regression -- the basic results do not change.

Note that the coefficient on the second social capital factor (which rises with social capital) in the basic regression in the first column of Table 5 is significantly negative: the higher the level of social capital in a prefecture, the lower the level of corporate tax returns collected.

In the second column, I add the number of small firms per capita. The coefficient is positive and significant: the more common small firms are in a prefecture, the higher the corporate tax revenues collected. This result reflects the extent to which large firms (that contribute to local GDP but pay taxes out of Tokyo headquarters) distort the results in the first column. After all, the greater the number of small firms in a prefecture, the smaller the role that the larger, national firms will play. The positive coefficient on small firm activity thus reflects the fact that prefectures with many small firms lose less tax revenue to Tokyo.

In the third column, I ask whether political affiliation affects the correlation between social capital and tax revenues. It does not. Adding the support for the longtime ruling Liberal Democratic Party does not change the coefficient on social capital, and does not produce statistically significant coefficients on itself.

\section{The Formal Judicial Process}

\section{A. Introduction:}

Scholars routinely claim that people and firms in communities with high levels of social capital more often keep their promises than those elsewhere. Embedded within dense networks of inter-laced social ties, they jeopardize a broader range of gains if they renege. They enjoy access to a wider source of aid to weather their crises. Even when those in more anomic worlds might break their commitments, people and firms in Coleman's "closed" societies obtain the help they need, and do as they promised. In Section B, I confirm this logic: at the Japanese prefectural level, social capital does indeed correlate with contractual performance.

I then ask whether people and firms in communities with high levels of social capital manipulate the formal legal apparatus as readily as those elsewhere. I ask whether they file as many lawsuits generally (Section C) -- and find ambiguous but suggestive evidence that (conditional on economic circumstance) litigation rates do indeed fall as social capital rises. I ask whether creditors file as many petitions to enforce their claims (e.g., enforce security interests, auction real estate; Section D) -and find that enforcement petition rates (conditional on economic circumstance) fall as social capital rises. Finally, I ask whether they file as many petitions for bankruptcy protection (Section E) -- and find that bankruptcy rates similarly fall as social capital rises.

\section{B. Contractual Performance:}

Contractual performance is hard to measure. No one documents the promises people keep or the contracts firms perform. For the most part, no one counts the commitments they break. Even less does anyone count the agreements they threaten to break and then renegotiate on more advantageous terms.

To measure how often firms renege on their promises I take the number of firms that default on two promissory notes within six months. Under the private rules 
of the clearinghouse for the banking industry, banks collectively agree not to extend further credit to any such firm. Effectively, they agree to place these firms on a cash basis and (what is the same thing) run them out of business (Ramseyer, 1991; Matsumura \& Ryser, 1995).

The firms that default are thus firms that took risks and that no one saved. Firms can minimize the risk of default by taking fewer chances. Once they anticipate default they can ask search for additional credit or ask banks and trade partners to renegotiate existing loans. Disproportionately, those that run afoul of the clearinghouse rules will be the firms that took the highest risks and found the fewest people willing to help.

Firms in prefectures with low levels of social capital do indeed more readily default. In Table 6, I regress the per capita rate of double defaults on the economic, educational, and social capital factors, and a separate variable capturing any economic growth over the preceding five years. As one would expect, the coefficient on GDP growth is significantly negative: the lower the rate of growth, the more likely firms default on their notes.

[Insert Table 6 about here.]

Central to this study, the coefficient on the second social capital factor (a factor that rises with social capital) is significantly negative: the higher the social capital, the lower the rate of default. Perhaps debtors take less risk with other people's money. Perhaps others more readily help troubled firms. Whatever the reason, defaults fall as social capital rises.

Consider two potential complications. First, Tokyo is an extreme outlier. It serves as home to about a tenth of the national population, and produces about a fifth of the GDP. Lest it skew the OLS results, in the second column I exclude Tokyo from the database. The results do not change.

Second, the social capital variables are potentially endogenous to the rate of firm failures. Recall that the variables are synthetic measures created through factor analysis on 11 proxies for the concept. Those proxies included job tenure and unemployment rates. Necessarily, these are endogenous to the rate at which firms default on their loans.

To address that endogeneity, in the third column I report two-stage leastsquares estimates. For this regression, I instrument the two social capital variables with a series of proxies for the level of social capital in the various prefectures during the mid-1920s. Inter-regional variation in social capital has been remarkably stable. Although the correlation between divorce rates in 1925 and 2010 is only .21 (significant at 16 percent), that between illegitimacy rates in 1925 and 2010 is .54 (significant at the 0.1 percent level). The correlation between 1925 illegitimacy rates and 2010 divorce rates is .30 (significant at 5 percent). The correlation between elementary school attendance rates in 1925 and performance on the 2013 middleschool standardized test is .32 (significant at 3 percent).

The two-stage estimates in the third column deliver the same message as the OLS estimates in the first: the higher the level of social capital, the lower the rate of default. The coefficient on the instrumented second social capital factor remains of the same order of magnitude as in the OLS estimates. The statistical significance increases further still.

\section{Civil Suits:}

In Table 7, I ask whether people and firms in prefectures with high levels of social capital file as many ordinary civil suits. To hold constant prefectural economic 
performance, in addition to the economic factor, I include the prefectural GDP growth rate used as an independent variable in Table 6 , and the rate of default used as the dependent variable in that table. Because the rate at which people file suits will turn on the availability of an attorney, I add the number of lawyers per capita.

[Insert Table 7 about here.]

I offer the basic regression in the first column. Preliminarily, note several characteristics. First, I exclude Tokyo. Not only does Tokyo house a tenth of the population and produce a fifth of GDP, it represents the residence of choice for half of all Japanese lawyers. For any study of the extent to which Japanese use the formal legal process, this obviously makes it a case unto itself. For comparative purposes, I offer the same regression on a database that does include Tokyo in the third column.

Second, I use two-stage least squares and instrument the number of attorneys. Although the availability of an attorney will obviously affect the rate at which people and firms file suits, attorneys will choose to work in areas where people and firms more willingly file suits. To address this obvious endogeneity, I instrument the per capita attorney population with the per capita population of their principal licensed rivals for non-litigation-related legal work (i.e., the so-called "judicial scriveners"). The latter offer a wide variety of office-based legal services: e.g., real estate conveyancing, administrative filings, estate administration. Other than over small claims, however, they may not represent parties in court. Following Ginsburg \& Hoetker (2006) and Ramseyer (2014), I use the number of these non-lawyer legal professionals to instrument the attorney population. For comparative purposes, I offer the same regression in ordinary least squares in the second column. As expected, the number of attorneys is positively, consistently, and statistically significantly correlated with the number of lawsuits.

Third, the three economic variables are highly correlated. The correlation between Insolvency PC and the synthetic economic factor is .47 (significant at 0.1 percent) and between Insolvency PC and the GDP growth rate is -.28 (significant at 6 percent). Given this colinearity, all but one of the calculated coefficients on the three variables in the four Table 7 regressions are statistically insignificant.

Fourth, despite these multiple economic controls, the social capital factors remain potentially endogenous. As Satyanath, et al. (2013) put it in their study of Nazi growth rates, people may have joined the Nazi party where "economic distress was high," and given their low opportunity cost invested more heavily in activities that built social capital. They address the possibility by instrumenting their measures of social capital with measures from the 19th century. I do the same in the fourth column by instrumenting the two social capital variables with proxies for the level of social capital in the 1920 s.

The basic regression in the first column suggests that the number of lawsuits rises as social capital falls. Note the significant positive coefficient on the first of the social capital factors. Given that this factor falls with social capital, a positive coefficient points to a negative correlation with litigation rates. The second social capital factor rises with social capital, however, and the coefficient on this variable is significantly positive as well. In part, the two variables thus offset each other.

The greater size (and statistical significance) of the first variable suggests a net negative relationship between social capital and litigation rates. In the basic regression in the first column, the coefficient on the first factor is about 50 percent bigger than the coefficient on the second. The variation in the two factors is similar: a standard deviation of .95 on the first and .91 on the second. As a result, an increase of one standard deviation in both factors would necessarily cause a larger effect 
through the first factor -- and indicate that litigation does indeed rise with social capital.

What is more, the positive coefficient on the second social factor results from the inclusion of other correlated independent variables. Suppose we look simply at a pairwise correlation between the social capital factor and the litigation rate (with Tokyo excluded). The correlation between the first factor and the litigation rate is positive and significant at the 0.1 percent level: litigation falls with social capital. The correlation between the second factor and the litigation rate is negative and significant at the 5 percent level: again, litigation falls with social capital.

Nonetheless, the tie between social capital and simple litigation rates remains ambiguous. First, as noted, the coefficients on social capital in the multivariate regressions move in opposite directions. Second, although the ordinary least square results in the second column yield results that closely track the two-stage estimates in the first, the coefficients from the regression that includes Tokyo (the third column) have no statistical significance. Last, when I instrument the two social capital factors with proxies from the 1920s, the statistical significance of the coefficient on the first social capital factor disappears entirely.

\section{Enforcement Petitions:}

Although Table 7 shows only an uncertain relation between social capital and general litigation rates, that ambiguity disappears when one focuses specifically on enforcement petitions (e.g., suits to auction real estate, suits to enforce security interests). In Table 8 I regress the per capita number of such petitions on the two social capital variables and several sets of controls. The results are clear: the higher the level of social capital, the fewer such court petitions.

[Insert Table 8 about here.]

Note two preliminary aspects of Table 8. First, I report four regressions -- the same variations reported in Table 7: a two-stage estimate (instrumenting Attorneys PC) without Tokyo, an ordinary least squares estimate without Tokyo, a two-stage estimate that includes Tokyo, and a two-stage estimate that instruments the social capital variables with 1920s proxies. Second, I control economic circumstance with the same variables used in Table 7: a synthetic economic factor, the five-year GDP growth rate, and the number of double-defaults per capita. Given the multicolinearity involved, none of the calculated coefficients on the economic variables is statistically significant.

Parenthetically, note two further observations. First, the number of attorneys consistently predicts high levels of enforcement petitions. Second, two regressions suggest that higher educational levels are associated with higher levels of enforcement petitions.

The calculated coefficient on the first social capital is significantly positive. ${ }^{2}$ Given that this factor falls with social capital, the import is clear: conditional on economic circumstance, the higher the level of social capital in a prefecture, the lower the rate at which people and firms file enforcement petitions. Perhaps firms take fewer risks. Perhaps troubled firms voluntarily make good to their creditors, or perhaps they can more readily obtain help. Whatever the reason, creditors in

\footnotetext{
2 In a pairwise correlation between the second social capital factor and the enforcement rate, the coefficient is negative and significant at the 10.1 percent rate.
} 
prefectures with high levels of social capital less often turn to the courts to enforce claims.

The magnitude of the effect of social capital is substantial. Take the results from the basic regression in the first column. A one standard-deviation change in the first social-capital factor (.95) produces a 14 percent change in the probability of a per capita enforcement filing from its median (.00087).

Table 9 explores which proxies for social capital might be driving the significant coefficient on social capital in Table 8. The table reports the coefficients from a series of regressions on Enforcement PC. In each regression, the independent variables were Attorneys PC (instrumented as discussed), the GDP growth rate, Insolvency PC, the Economic factor, the Educational factor 1, the Educational factor 2, and one each of the 11 proxies used to construct the two social capital factors.

The most highly significant coefficients appear on the family variables: the strongest proxy for enforcement filings is the prefectural Illegitimacy rate. Indeed, the pairwise correlation coefficient between the Illegitimacy rate and Enforcement PC is a staggering .70 (significant at 0.1 percent). The Divorce rate is also significant, but the coefficient on each of the other variables is statistically insignificant. Colinearity with the the economic controls reduces the statistical significance of the coefficient on the (otherwise important) economic proxies to insignificant levels: in pairwise correlations, the Unemployment rate is correlated with Enforcement PC at .54 (significant at 0.1 percent), the College graduate unemployment rate is correlated with Enforcement PC at .46 (significant at 0.1 percent), and Job tenure is correlated at .42 . (significant at 0.1 percent).

[Insert Table 9 about here.]

\section{E. Bankruptcy Petitions:}

The regressions on bankruptcy filings similarly present no ambiguity: economic circumstances held constant, petitions for formal bankruptcy protection rise as social capital falls (see Table 10). If a firm simply defaults on a note, the banks will collectively place it on a cash basis and drive it into failure. By filing for bankruptcy protection, the firm can sometimes force its creditors to take less than promised. Firms more often do this, according to the regressions in Table 10, in the prefectures with the lowest levels of social capital.

[Insert Table 10 about here.]

I use the same presentation as in Tables 7 and 9. I again report four regressions: a two-stage estimate (instrumenting Attorneys PC) without Tokyo, an ordinary least squares estimate without Tokyo, a two-stage estimate that includes Tokyo, and a two-stage estimate that instruments the social capital variables with 1920s proxies. I use the same economic controls: a synthetic economic factor, the five-year GDP growth rate, and the number of double-defaults per capita. Given the multi-colinearity involved, the economic variables again generate statistically insignificant results.

Again, note two further observations. First, the coefficient on the second educational factor is consistently positive and significant: economic circumstances held constant, the rate of bankruptcy petitions rises with education. ${ }^{3}$ Second, in two

\footnotetext{
${ }^{3}$ In a pairwise correlation between the second social capital factor and the bankruptcy filing rate, the coefficient is negative and significant at the 15.4 percent rate.
} 
of the four regressions, the number of attorneys is positively associated with the number of bankruptcy petitions. In the other two regressions, the coefficient is insignificant.

The coefficient on the first social capital variable is consistently positive and significant. Given that the variable falls with social capital, the import is straightforward: the greater level of social capital, the less often distressed firms file for bankruptcy protection. Note that this holds true even when I instrument the variable with social-capital proxies from the 1920s. Either firms in high social-capital prefectures take less risk with borrowed money, or when in distress they successfully negotiate workable arrangements outside the courts.

The magnitude of the effect of social capital is again substantial. Take the basic regression in the first column. A one standard-deviation change in the first social capital factor (.95) produces a 20 percent change in the probability of a per capita bankruptcy filing from its median (.00086).

Table 11 explores which proxies used in the factor analysis might be driving the significant coefficient on social capital in Table 10. I report the coefficients from a series of regressions on Bankruptcy PC. I use the same independent variables as in Table 9.

[Insert Table 11 about here.]

The most strongly significant coefficients again appear on the family variables: the Illegitimacy rate and the Divorce rate. The pairwise correlation between the Illegitimacy rate and Bankruptcy PC is .52 (significant at 0.1 percent) Statistically significant results also appear on the number of Religious followers per capita, Community center staff per capita, the Unemployment rate, and the Divorce settlement rate. Given the correlation coefficient of -.25 (significant at 10 percent) between Job tenure and Bankruptcy PC, the insignificant coefficient on Job tenure in the regression probably results from the correlation between the variable and the multiple economic control variables.

\section{Mechanisms}

Where social capital is high, people more often do as expected. Integrated into broad social networks, they convey information to each other quickly and widely -- and learn about those who violate social norms. Participating in a broad range of indefinitely repeated relationships, they find it advantageous to punish those who violate those norms -- even when not harmed them themselves. And able (through these mechanisms) more credibly to promise to perform, when in financial distress they can more successfully tap the needed help.

This logic suggests two related yet fundamentally distinct mechanisms for the empirical results above. The first is straightforward. Where social capital is high, residents can more readily enforce their deals informally. Given the risk of informal sanctions, contractual partners are less likely to renege on their promises (Table 6). When they do default, creditors more readily enforce their agreements out of court (Table 8). And given the force of those communal sanctions, debtors less often skirt their promises through bankruptcy filings (Table 10).

A related -- but distinct-- explanation turns on access to credit. Where residents interact with each other in a wide range of relationships, creditors can more accurately gauge the risk that a debtor presents and more effectively enforce repayment. A debtor, in turn, can more credibly promise to repay. As a result, where social capital is high, distressed debtors will have better access to informal sources of credit. 
Consider what follows from this access to informal loans. Suppose a small firm borrows from a bank but falls into distress. It defaulted on one promissory note last month, and is about to default again. Where social capital is low, it will simply default (Table 6). Where social capital is high, however, the CEO may be able to borrow informally. Perhaps he will borrow from a friend, or perhaps from his older brother. He will take out that informal loan, pay his bank, and avoid the second default.

Suppose the CEO in the high-social-capital community does borrow from his brother and repay the bank. Because the bank will have obtained its money, it will not sue to enforce any security interest (Table 8). Of course, the CEO's older brother may find himself saddled with a bad loan -- but older brothers seldom sue in court.

And suppose the firm eventually fails. Where social capital is low, the firm's CEO will not have borrowed informally, so the firm will fail with debt outstanding at the local bank. Rather than pay, it will file for bankruptcy and skirt repayment (Table 10). Where social capital is high, though, it will fail owing money to the CEO's brother. It will not file for bankruptcy protection for a simple reason -- few people anywhere file for bankruptcy protection to avoid paying older brothers.

\section{Conclusions}

Most people everywhere try to keep their word when they can, but in some societies they try particularly hard. Firms perform their contracts when able. When they find performance impossible, they work with their creditors to make the best of the bad circumstances, and try to find an outcome satisfactory to them both. Courts and formal legal institutions they largely ignore.

Investments in social capital give a way to identify these worlds. Whether firms negotiate and perform independent of the formal judicial apparatus turns on the extent to which people locate themselves within webs of social ties:

Do they marry? Do they bear and raise their children within marriage?

Do they vote? Do they volunteer at community activities? Do they attend religious services? Do they sing in choral societies?

Or do they bowl alone?

Measure the density of the networks within which people live, work, negotiate, and invest, and we can start to locate the communities where they stay largely outside the ambit of the formal legal system.

In Japan, levels of social capital do indeed identify the worlds where people most often keep their word. To locate those communities, I identify multiple proxies for the levels of social capital in the community -- though not the famous choral societies or bowling leagues. Through factor analysis, I then use those proxies to approximate that underlying social capital. In prefectures with relatively high levels of social capital, I find that people more willingly comply with many low-level legal mandates -- particularly if the government does not actively enforce compliance through civil litigation and criminal prosecution. Debtors less often default on their debt. They less often try to skirt their obligations through bankruptcy filings. And creditors less often enforce their claims through the formal court process. 
Table 1: Selected Summary Statistics

A. Dependent Variables:

Minimum Mean Median Maximum

(Traffic violations)/roads

NHK payment rate

$\begin{array}{llll}1.650 & 7.078 \quad 4.498 & 46.513\end{array}$

Pension contribution rate

$\begin{array}{llll}42.0 & 77.8 & 78.9 & 94.6\end{array}$

(Self-rep pers tax)/GDP (e-06)

42.9

65.7

66.0

75.2

(Total personal tax)/GDP (e-05)

2.34

3.70

3.27

7.33

(Corp tax)/(Non-agri GDP) (e-06)

Insolvency $P C(\mathrm{e}-05)$

1.33

2.00

1.82

6.73

Lawsuits PC (e-04)

4.38

11.00

9.41

43.8

Bankruptcy PC (e-04)

3.54

8.39

7.17

23.83

9.19

14.77

13.86

40.61

Enforcement PC (e-05)

6.14

9.49

8.57

18.78

9.4

88.44

86.65

126.7

B. Proxies variables:

Income PC
Savings PC
Foreign auto fraction
Advance to high school
Expenses per stud, elem
Expenses per stud, middle
Expenses per stud, high
Standardized test, mean
Standardized test, middle
Truancy rate

Truancy rate

Voter turnout

Volunteering

$\begin{array}{llll}4559 & 6823 & 6830 & 8336\end{array}$

$\begin{array}{llll}5068 & 14887 & 15647 & 19577\end{array}$

$\begin{array}{llll}1.5 & 4.28 & 4.2 & 7.6\end{array}$

$\begin{array}{llll}92.8 & 96.5 & 96.7 & 98.4\end{array}$

$\begin{array}{llll}761 & 924.1 & 905 & 1211\end{array}$

$890 \quad 1065.2 \quad 1027 \quad 1474$

$\begin{array}{llll}941 & 1171.4 & 1141 & 2173\end{array}$

$\begin{array}{llll}55.8 & 62.2 & 62.0 & 69.2\end{array}$

$\begin{array}{llll}53.7 & 62.3 & 62.5 & 68.2\end{array}$

$\begin{array}{llll}1.83 & 2.53 & 2.56 & 3.11\end{array}$

$\begin{array}{llll}38.19 & 59.46 & 58.77 & 69.44\end{array}$

Community center staff PC (e-05)

19.7

28.2

27.6

34.5

Religious followers PC

crime rate

2.26

13.34

11.24

44.31

.625

1.720

1.485

6.473

4.99

10.50

10.02

18.87

8.7

11.5

11.6

13.0

Unemployment rate

Unemployment, college grad

Divorce rate

3.2

4.8

4.7

7.5

7.5

21.8

21.5

42.7

$.289 \quad .375$

.374

.452

.804

.869

.871

.921

Illegitimacy rate

1.29

2.15

2.10

3.99

C. Other Independent Variables:

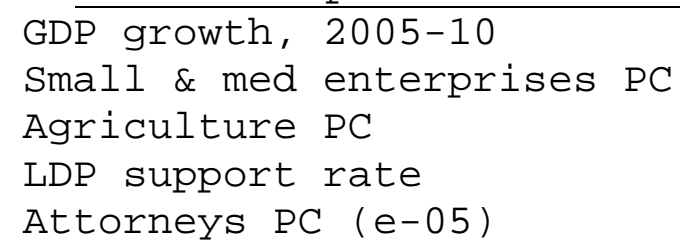

Small \& med enterprises PC

Agriculture PC

LDP support rate

Attorneys PC (e-05)

$\begin{array}{llll}-.126 & -.046 & -.045 & .027 \\ 35.1 & 80.40 & 82.40 & 92.10 \\ .13 & 3.97 & 4.20 & 8.23 \\ 17.64 & 26.87 & 26.78 & 38.59 \\ 5.81 & 12.64 & 9.40 & 107.56\end{array}$

D. Instrument:

Scriveners PC

(Continued on next page) 


\section{Table 1 (Continued)}

E. Synthetic Variables: Economic factor Educational factor 1 Educational factor 2 other social capital 1

$\begin{array}{llll}-2.176 & .000 & .048 & 2.914 \\ -3.237 & -.00 \odot & -.033 & 2.878 \\ -1.632 & .00 \odot & -.187 & 2.911 \\ -1.692 & .000 & -.195 & 3.275 \\ -1.972 & .000 & .135 & 1.931\end{array}$
other social capital 2 


\section{Table 2: Rotated Factor Loadings}

A. Economic Factor:

\begin{tabular}{|c|c|c|}
\hline Variable | & Factor1 & Uniqueness \\
\hline$-t$ & -- & ------ \\
\hline Income PC & 0.8150 & 0.3357 \\
\hline Savings PC & 0.7278 & 0.4703 \\
\hline Foreign Autol & $\odot .8574$ & 0.2649 \\
\hline
\end{tabular}

B. Education Factor:

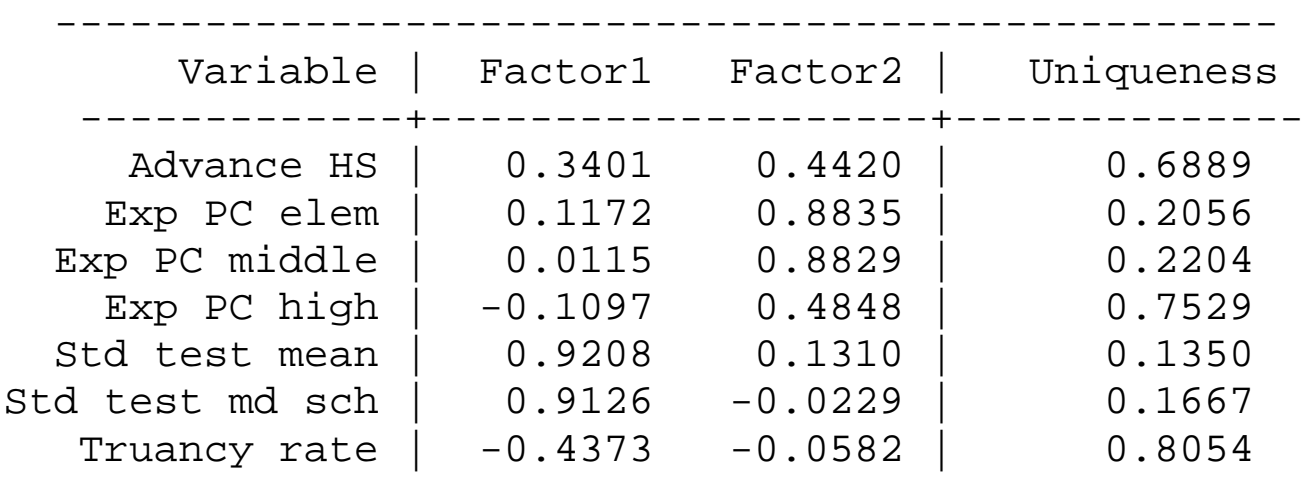

C. Other Aspects of Social Capital

\begin{tabular}{|c|c|c|c|}
\hline Variable | & Factor 1 & Factor 2 & Uniqueness \\
\hline & & & \\
\hline Divorce rate| & 0.7094 & 0.1321 & $\odot .4793$ \\
\hline $\mathrm{D}$ settlemt $r t$ & 0.5578 & $-\odot .4714$ & 0.4667 \\
\hline Voter turnout & -0.3916 & 0.6585 & 0.4130 \\
\hline Volunteering & -0.2539 & 0.7921 & 0.3081 \\
\hline Cmtyctr st PCI & -0.2170 & 0.6601 & 0.5171 \\
\hline Rel follwr PC| & -0.3423 & 0.2640 & 0.8132 \\
\hline Crime rate| & -0.0769 & -0.7001 & 0.5039 \\
\hline Job tenure| & -0.7383 & $\odot .1968$ & 0.4162 \\
\hline Unemployment | & 0.6600 & $-\odot .4698$ & 0.3436 \\
\hline Unemp col gri & 0.6303 & $-\odot .2842$ & 0.5220 \\
\hline Illegitimacy| & $\odot .8757$ & -0.2131 & 0.1878 \\
\hline
\end{tabular}

Notes: The table gives the rotated factor loadings for the synthetic measures of the Economic factor, the Educational factors, and other Social Capital measures. Principal factors method used. Orthogonal varimax rotation results reported. Factors retained if eigenvalue $>1$. 


\section{Table 3: Low-Stakes Social Norms}

\begin{tabular}{|c|c|c|c|}
\hline Dependent variable: & $\begin{array}{l}\text { NHK fee } \\
\text { payment rate }\end{array}$ & $\begin{array}{l}\text { National pension } \\
\text { payment rate }\end{array}$ & $\begin{array}{l}\text { Traffic } \\
\text { ticket rate }\end{array}$ \\
\hline Economic factor & $\begin{array}{l}-4.114 \\
(3.20) * * *\end{array}$ & $\begin{array}{l}-.292 \\
(0.40)\end{array}$ & $\begin{array}{l}7.358 \\
(5.09) * * *\end{array}$ \\
\hline Educational factor 1 & $\begin{array}{l}3.036 \\
(3.38) * * *\end{array}$ & $\begin{array}{l}.804 \\
(1.59)\end{array}$ & $\begin{array}{l}.633 \\
(0.63)\end{array}$ \\
\hline Educational factor 2 & $\begin{array}{l}.874 \\
(1.07)\end{array}$ & $\begin{array}{l}1.270 \\
(2.76) * * *\end{array}$ & $\begin{array}{l}1.494 \\
(1.62)\end{array}$ \\
\hline other social cap 1 & $\begin{array}{l}-4.959 \\
(4.50) * * *\end{array}$ & $\begin{array}{l}-3.616 \\
(5.83) * * *\end{array}$ & $\begin{array}{l}3.088 \\
(2.49) * *\end{array}$ \\
\hline other social cap 2 & $\begin{array}{l}3.44 \\
(2.67) * \star\end{array}$ & $\begin{array}{l}3.090 \\
(4.66) * * *\end{array}$ & $\begin{array}{l}-1.490 \\
(1.12)\end{array}$ \\
\hline Adj R2 & .75 & .80 & .58 \\
\hline $\mathrm{n}$ & 47 & 47 & 47 \\
\hline
\end{tabular}

Notes: $* * *, * *, *$, significant at the 1,5 , and 10 percent levels. Coefficient, followed by absolute value of t-statistic in parenthesis. 


\section{Table 4: Tax Evasion -- Personal}

\section{A. Self-reported personal tax:}

Dependent variable:

Economic factor

Educational factor 1

Educational factor 2

other social cap 1

other social cap 2

Agricultural rate

LDP support

Adj R2

$\mathrm{n}$
(Self-reported personal tax)/GDP

\begin{tabular}{|c|c|c|}
\hline $\begin{array}{l}1.98 \mathrm{e}-07 \\
(0.78) \\
9.14 \mathrm{e}-08 \\
(0.53) \\
-1.57 \mathrm{e}-07 \\
(0.99) \\
1.82 \mathrm{e}-07 \\
(0.75) \\
-8.03 \mathrm{e}-07 \\
(4.26)^{* \star *}\end{array}$ & $\begin{array}{l}-1.04 \mathrm{e}-\odot 7 \\
(0.43) \\
1.33 \mathrm{e}-\odot 7 \\
(\odot .86) \\
-1.32 \mathrm{e}-\odot 8 \\
(0.09) \\
8.94 \mathrm{e}-\odot 8 \\
(0.41) \\
-3.82 \mathrm{e}-\odot 7 \\
(1.82)^{*} \\
-3.57 \mathrm{e}-\odot 7 \\
(3.37)^{* * *}\end{array}$ & $\begin{array}{l}-1.35 \mathrm{e}-07 \\
(0.56) \\
2.06 \mathrm{e}-\odot 7 \\
(1.29) \\
2.99 \mathrm{e}-\odot 8 \\
(0.20) \\
8.44 \mathrm{e}-08 \\
(0.39) \\
-2.38 \mathrm{e}-07 \\
(1.04) \\
-3.70 \mathrm{e}-07 \\
(3.52) * * * \\
-4.65 \mathrm{e}-08 \\
(1.45)\end{array}$ \\
\hline .44 & .55 & .56 \\
\hline 47 & 47 & 47 \\
\hline
\end{tabular}

B. All personal tax:

Dependent variable:

(Total personal tax)/GDP

Economic factor

Educational factor 1

$6.00 \mathrm{e}-06$

$4.94 \mathrm{e}-06$

$(3.03)^{* * *}$

$(3.85) * * *$

$1.48 \mathrm{e}-06$

$(1.26)$

Educational factor 2

$2.58 \mathrm{e}-06$

$(2.65)$ * *

other social cap 1

$2.93 e-06$

$(1.97)$ *

other social cap 2

$-4.58 \mathrm{e}-06$

$(3.94)^{* * *}$

Agricultural rate

LDP support

$(1.43)$

3. $09 \mathrm{e}-06$

$(3.11) * * *$

$2.61 \mathrm{e}-06$

$(1.78)^{*}$

$-3.11 \mathrm{e}-06$

$(2.20)$ * *

$-1.25 \mathrm{e}-06$

$(1.75)^{*}$

$4.87 \mathrm{e}-06$

$(2.94)^{* * *}$

$1.66 \mathrm{e}-06$

(1.51)

$3.19 \mathrm{e}-06$

$(3.12)^{* * *}$

2.59e-06

$(1.76)$ *

$-2.76 \mathrm{e}-06$

$(1.74)$ *

$-1.28 \mathrm{e}-06$

$(1.77)$ *

$-1.13 e-07$

$(0.51)$

.55

.57

.56

47

47

47

Notes: $* * *, * *, *$, significant at the 1,5 , and 10 percent levels. Coefficient, followed by absolute value of $t$-statistic in parenthesis. 


\section{Table 5: Tax Evasion -- Corporate}

\begin{tabular}{|c|c|c|c|c|}
\hline Dependent variable: & \multicolumn{4}{|c|}{ (Corporate tax)/(Non-agri'l GDP) } \\
\hline Economic factor & $\begin{array}{l}-1.04 \mathrm{e}-07 \\
(0.08)\end{array}$ & $\begin{array}{l}-1.36 e-07 \\
(0.11)\end{array}$ & $\begin{array}{l}-1.30 \mathrm{e}-07 \\
(0.10)\end{array}$ & $\begin{array}{l}4.30 \mathrm{e}-06 \\
(3.26) * * *\end{array}$ \\
\hline Educational factor 1 & $\begin{array}{l}-4.20 \mathrm{e}-07 \\
(0.58)\end{array}$ & $\begin{array}{l}-4.24 \mathrm{e}-07 \\
(0.64)\end{array}$ & $\begin{array}{l}-3.46 \mathrm{e}-07 \\
(0.48)\end{array}$ & $\begin{array}{l}5.40 \mathrm{e}-07 \\
(0.57)\end{array}$ \\
\hline Educational factor 2 & $\begin{array}{l}-6.45 e-07 \\
(0.81)\end{array}$ & $\begin{array}{l}-1.20 \mathrm{e}-06 \\
(1.57)\end{array}$ & $\begin{array}{l}-1.16 \mathrm{e}-06 \\
(1.48)\end{array}$ & $\begin{array}{l}1.32 \mathrm{e}-06 \\
(1.51)\end{array}$ \\
\hline other social cap 1 & $\begin{array}{l}-7.92 \mathrm{e}-07 \\
(0.72)\end{array}$ & $\begin{array}{l}-6.19 \mathrm{e}-07 \\
(0.61)\end{array}$ & $\begin{array}{l}-6.00 \mathrm{e}-07 \\
(0.58)\end{array}$ & $\begin{array}{l}1.95 \mathrm{e}-06 \\
(1.55)\end{array}$ \\
\hline other social cap 2 & $\begin{array}{l}-1.54 \mathrm{e}-06 \\
(1.94)^{*}\end{array}$ & $\begin{array}{l}-1.77 \mathrm{e}-06 \\
(2.40)^{* *}\end{array}$ & $\begin{array}{l}-1.64 \mathrm{e}-06 \\
(1.98)^{*}\end{array}$ & $\begin{array}{l}-2.22 \mathrm{e}-06 \\
(2.00)^{*}\end{array}$ \\
\hline Small \& medium ent PC & & $\begin{array}{l}3.41 \mathrm{e}-04 \\
(2.83) * * *\end{array}$ & $\begin{array}{l}3.51 \mathrm{e}-04 \\
(2.79) * \star *\end{array}$ & $\begin{array}{l}3.94 e-04 \\
(2.33) \star \star\end{array}$ \\
\hline LDP support & & & $\begin{array}{l}-4.77 e-08 \\
(0.33)\end{array}$ & $\begin{array}{l}-1.44 \mathrm{e}-07 \\
(0.74)\end{array}$ \\
\hline Adj R2 & .11 & .24 & .23 & .43 \\
\hline 11 & 46 & 46 & 46 & 47 \\
\hline Tokyo included: & No & No & No & Yes \\
\hline
\end{tabular}

Notes: $* * *, * *, *$, significant at the 1,5 , and 10 percent levels. Coefficient, followed by absolute value of $\mathrm{t}$-statistic in parenthesis. 


\section{Table 6: Insolvency Rates}

\begin{tabular}{|c|c|c|c|}
\hline Dependent variable: & & solvency $P$ & \\
\hline GDP growth & $\begin{array}{l}-3.51 \mathrm{e}-04 \\
(2.15)^{* *}\end{array}$ & $\begin{array}{l}-3.44 \mathrm{e}-\odot 4 \\
(2.12)^{* *}\end{array}$ & $\begin{array}{l}-4.25 e-04 \\
(2.03)^{\star *}\end{array}$ \\
\hline Economic factor & $\begin{array}{l}1.85 e-05 \\
(2.01)^{*}\end{array}$ & $\begin{array}{l}1.01 \mathrm{e}-05 \\
(0.87)\end{array}$ & $\begin{array}{l}5.59 \mathrm{e}-07 \\
(0.03)\end{array}$ \\
\hline Educational factor 1 & $\begin{array}{l}7.47 \mathrm{e}-06 \\
(1.20)\end{array}$ & $\begin{array}{l}6.10 \mathrm{e}-06 \\
(0.96)\end{array}$ & $\begin{array}{l}1.21 \mathrm{e}-05 \\
(1.39)\end{array}$ \\
\hline Educational factor 2 & $\begin{array}{l}4.80 \mathrm{e}-06 \\
(\odot .82)\end{array}$ & $\begin{array}{l}2.17 \mathrm{e}-07 \\
(\odot .03)\end{array}$ & $\begin{array}{l}8.55 e-06 \\
(1.14)\end{array}$ \\
\hline other social cap 1 & $\begin{array}{l}1.06 \mathrm{e}-05 \\
(1.18)\end{array}$ & $\begin{array}{l}5.77 \mathrm{e}-06 \\
(0.58)\end{array}$ & $\begin{array}{l}8.28 \mathrm{e}-06 \\
(0.49)\end{array}$ \\
\hline Other social cap 2 & $\begin{array}{l}-1.9 \mathrm{e}-05 \\
(2.76)^{* * *}\end{array}$ & $\begin{array}{l}-1.74 \mathrm{e}-05 \\
(2.50)^{* *}\end{array}$ & $\begin{array}{l}-5.18 \mathrm{e}-05 \\
(3.29)^{* * *}\end{array}$ \\
\hline Adj R2 & .33 & .19 & -.03 \\
\hline $\mathrm{n}$ & 47 & 46 & 46 \\
\hline Tokyo included: & Yes & No & Yes \\
\hline Regression & OLS & OLS & $2 \mathrm{SLS}$ \\
\hline
\end{tabular}

Notes: $* * *, * *, *$, significant at the 1,5 , and 10 percent levels. Coefficient, followed by absolute value of t-statistic in parenthesis. In the third column, other social capital 1 and other social capital 2 are instrumented by Divorce rate 1925, Illegitimacy rate 1925, Young wife rate 1925, Elem school attend 1925, Emmigrants 1899-1941 PC, Tenancy rate 1923, Tenant riots 1912-26 PC, Prostitute birthplace 1924 PC, Geisha birthplace 1924 PC, Barmaid birthplace 1926 PC, and Infant mortality sex ratio 1925. $\mathrm{n}$ falls to 46 in the last column because Tenancy rate 1923 omits Okinawa. 


\section{Table 7: Civil Suit Rates}

Dependent variable:

Insolvency PC

Attorneys PC

GDP growth

Economic factor

Educational factor 1

Educational factor 2

other social cap 1

other social cap 2

Adj R2

$\mathrm{n}$

Tokyo included:

Regression

-1.508
$(0.26)$
13.545
$(2.54)^{* *}$
$6.35 \mathrm{e}-03$
$(1.67)$
$-1.56 \mathrm{e}-04$
$(0.63)$
$1.28 \mathrm{e}-04$
$(0.90)$
$7.78 \mathrm{e}-05$
$(0.52)$
$4.89 \mathrm{e}-04$
$(2.38) * *$
$3.18 \mathrm{e}-04$
$(1.77)^{*}$

.61

46

No

2SLS
Lawsuits $P C$

.571
$(0.14)$
11.234
$(3.79)^{\star * *}$
$5.69 \mathrm{e}-03$
$(1.60)$
$-1.86 \mathrm{e}-\odot 4$
$(0.77)$
$1.03 \mathrm{e}-\odot 4$
$(0.78)$
$5.78 \mathrm{e}-05$
$(0.40)$
$5.07 \mathrm{e}-\odot 4$
$(2.52)^{\star *}$
$2.76 \mathrm{e}-\odot 4$
$(1.73)^{\star}$

.360

$(0.07)$

9.718

$(3.62)$ ***

5. $06 \mathrm{e}-03$

(1.34)

$-5.79 \mathrm{e}-04$

(1.65)

3. 3e- 05

$(0.24)$

$-1.69 \mathrm{e}-04$

$(0.83)$

$3.02 \mathrm{e}-04$

(1.06)

$2.94 \mathrm{e}-04$

$(1.60)$

.840

$(0.18)$

13.593

$(3.54)^{* * *}$

$7.89 \mathrm{e}-03$

$(1.71)$ *

$-1.09 \mathrm{e}-04$

$(0.29)$

$7.26 \mathrm{e}-06$

$(0.04)$

$-3.69 \mathrm{e}-05$

$(0.21)$

$5.53 e-04$

(1.49)

$6.51 \mathrm{e}-04$

$(1.84)$ *

$\begin{array}{lll}.61 & .70 & .54 \\ 46 & 47 & 45 \\ \text { No } & \text { Yes } & \text { No } \\ \text { OLS } & 2 S L S & 2 S L S\end{array}$

Notes: $* * *, * *, *$, significant at the 1,5 , and 10 percent levels. Coefficient, followed by absolute value of t-statistic in parenthesis. In the first and third columns, Attorneys PC is instrumented by Scriveners PC. In the fourth column, other social capital 1 and other social capital 2 are instrumented by Divorce rate 1925, Illegitimacy rate 1925, Young wife rate 1925, Elem school attend 1925, Emmigrants 1899-1941 PC, Tenancy rate 1923, Tenant riots 1912-26 PC, Prostitute birthplace 1924 PC, Geisha birthplace 1924 PC, Barmaid birthplace 1926 PC, and Infant mortality sex ratio 1925. $n$ falls in the last column because Tenancy rate 1923 omits Okinawa. 
Table 8: Enforcement Petition Rates

Dependent variable:

Insolvency PC

Attorneys PC

GDP growth

Economic factor

Educational factor 1

Educational factor 2

Other social cap 1

other social cap 2

Adj R2

$\mathrm{n}$

Tokyo included:

Regression

-.828
$(0.72)$
1.979
$(1.86)^{*}$
$1.059 \mathrm{e}-03$
$(1.40)$
$5.62 \mathrm{e}-05$
$(1.13)$
$8.02 \mathrm{e}-07$
$(0.03)$
$5.85 \mathrm{e}-05$
$(1.96)^{*}$
$1.31 \mathrm{e}-04$
$(3.20)^{\star * *}$
$2.8 \mathrm{e}-05$
$(0.78)$

.55

46

No

2SLS
Enforcement $P C$

-.818
$(0.97)$
1.967
$(3.30)^{\star * *}$
$1.056 \mathrm{e}-03$
$(1.48)$
$5.6 \mathrm{e}-05$
$(1.16)$
$6.82 \mathrm{e}-07$
$(0.03)$
$5.84 \mathrm{e}-05$
$(2.02)^{*}$
$1.311 \mathrm{e}-04$
$(3.24)^{\star * *}$
$2.78 \mathrm{e}-05$
$(0.86)$

-.370
$(0.34)$
1.042
$(1.82)^{\star}$
$7.436 \mathrm{e}-04$
$(0.92)$
$-4.76 \mathrm{e}-05$
$(0.63)$
$-2.24 \mathrm{e}-05$
$(0.76)$
$-1.83 \mathrm{e}-06$
$(0.04)$
$8.5 \mathrm{e}-05$
$(1.40)$
$2.22 \mathrm{e}-05$
$(0.57)$

$-.876$

(1.02)

2.179

$(3.04)^{* * *}$

1. $321 \mathrm{e}-03$

(1.54)

$3.47 \mathrm{e}-05$

$(0.50)$

$-1.99 \mathrm{e}-05$

$(0.62)$

$3.98 \mathrm{e}-05$

(1.23)

$1.189 \mathrm{e}-04$

$(1.71)^{*}$

$5.37 e-05$

$(0.81)$

$\begin{array}{ll}.44 & .54 \\ 47 & 45 \\ \text { Yes } & \text { No }\end{array}$

OLS

2SLS

Notes: $* * *, * *, *$, significant at the 1,5 , and 10 percent levels. Coefficient, followed by absolute value of t-statistic in parenthesis. In the third column, Attorneys PC is instrumented by Scriveners PC. In the fourth column, other social capital 1 and other social capital 2 are instrumented by Divorce rate 1925, Illegitimacy rate 1925, Young wife rate 1925, Elem school attend 1925, Emmigrants 1899-1941 PC, Tenancy rate 1923, Tenant riots 1912-26 PC, Prostitute birthplace 1924 PC, Geisha birthplace 1924 PC, Barmaid birthplace 1926 PC, and Infant mortality sex ratio 1925. $\mathrm{n}$ falls in the last column because Tenancy rate 1923 omits Okinawa. 


\section{Table 9: Serial Enforcement Regressions on Proxies for Social Capital}

Dependent Variable:

Divorce rate

Divorce settlement rate

Voter turnout

Volunteering

Community center staff, PC

Religious followers, PC

Crime rate

Job tenure

Unemployment

Unemployment, college graduates

Illegitimacy
Bankruptcy $P C$

$1.627 e-03(2.01)$ *

$2.244 \mathrm{e}-03(1.49)$

$1.95 \mathrm{e}-06 \quad(0.32)$

$1.18 \mathrm{e}-06 \quad(0.16)$

$.146 \quad(0.42)$

$-1.04 \mathrm{e}-05(0.45)$

$7.42 \mathrm{e}-07 \quad(0.05)$

$-3.31 e-05(0.68)$

$1.37 \mathrm{e}-05 \quad(0.28)$

$2.46 \mathrm{e}-06 \quad(0.45)$

$1.827 \mathrm{e}-04(2.71)$

Notes: $* * *, * *, *$, significant at the 1,5 , and 10 percent levels. The table gives the coefficient, followed by the absolute value of the t-statistic. Note that each independent variable appeared in a separate regression. In each case, the dependent variable in the regression is Bankruptcy PC. The regression is two-stage least squares, and excludes Tokyo. In each regression, the independent variables included Attorneys PC (instrumented by Scriveners PC), GDP growth rate, Insolvency PC, Economic factor, Educational factor 1, Educational factor 2, and one of the variables above. 
Table 10: Bankruptcy Petition Rates

Dependent variable:

Insolvency PC

Attorneys PC

GDP growth

Economic factor

Educational factor 1

Educational factor 2

Other social cap 1

other social cap 2

Adj R2

$\mathrm{n}$

Tokyo included:

Regression

1.821
$(1.33)$
.046
$(0.04)$
$-8.89 \mathrm{e}-04$
$(0.99)$
$3.57 \mathrm{e}-05$
$(0.61)$
$3.42 \mathrm{e}-05$
$(1.02)$
$1.07 \mathrm{e}-04$
$(3.00)^{* * *}$
$1.83 \mathrm{e}-04$
$(3.77)^{* * *}$
$-2.36 \mathrm{e}-05$
$(0.56)$

.50

46

No

2SLS
Bankruptcy $P C$

.191
$(0.21)$
1.858
$(2.90)^{\star * *}$
$-3.71 \mathrm{e}-04$
$(0.48)$
$5.93 \mathrm{e}-05$
$(1.14)$
$5.32 \mathrm{e}-05$
$(1.86)^{*}$
$1.22 \mathrm{e}-04$
$(3.93)^{\star * *}$
$1.70 \mathrm{e}-\odot 4$
$(3.90)^{\star * *}$
$8.86 \mathrm{e}-06$
$(0.26)$

$$
\begin{aligned}
& 1.681 \\
& (1.55) \\
& .334 \\
& (0.58) \\
& -7.92 \mathrm{e}-04 \\
& (0.98) \\
& 6.76 \mathrm{e}-05 \\
& (0.90) \\
& 4.13 \mathrm{e}-05 \\
& (1.39) \\
& 1.25 \mathrm{e}-04 \\
& (2.89)^{\star * *} \\
& 1.97 \mathrm{e}-04 \\
& (3.25)^{* * *} \\
& -2.18 \mathrm{e}-05 \\
& (0.56)
\end{aligned}
$$

$-.195$

$(0.28)$

1.788

$(3.08) * * *$

$-3.38 \mathrm{e}-04$

$(0.49)$

$-1.14 \mathrm{e}-05$

$(0.20)$

$1.14 \mathrm{e}-05$

$(0.44)$

$8.45 \mathrm{e}-05$

$(3.22)^{* * *}$

$1.64 \mathrm{e}-04$

$(2.92)^{* * *}$

$-1.55 \mathrm{e}-05$

$(0.29)$

.65

.77

47

45

46

Yes

No

2SLS

Notes: $* * *, * *, *$, significant at the 1,5 , and 10 percent levels. Coefficient, followed by absolute value of t-statistic in parenthesis. In the first and third column, Attorneys PC is instrumented by Scriveners PC. In the fourth column, other social capital 1 and other social capital 2 are instrumented by Divorce rate 1925 , Illegitimacy rate 1925 , Young wife rate 1925 , Elem school attend 1925, Emmigrants 1899-1941 PC, Tenancy rate 1923 Tenant riots 1912-26 PC, Prostitute birthplace 1924 PC, Geisha birthplace 1924 PC, Barmaid birthplace 1926 PC, and Infant mortality sex ratio 1925. $n$ falls in the last column because Tenancy rate 1923 omits Okinawa. 
Table 11: Serial Bankruptcy Regressions on Proxies for Social Capital

Dependent Variable:

Bankruptcy PC

Divorce rate

Divorce settlement rate

$2.661 \mathrm{e}-03(3.08) * * *$

Voter turnout

$3.586 \mathrm{e}-03(1.79)$ *

Volunteering

$-2.79 e-06(0.38)$

Community center staff, PC

$-3.33 e-06(0.38)$

Religious followers, PC

$-.781$

$(2.06) * *$

Crime rate

$-7.05 \mathrm{e}-05(3.03) * * *$

Job tenure

$2.62 \mathrm{e}-05 \quad(1.62)$

Unemployment

Unemployment, college graduates

$-6.79 e-05(1.13)$

$1.009 \mathrm{e}-04(1.97)$ *

Illegitimacy

1. $54 \mathrm{e}-07$

$2.985 e-04(3.29)$ ** *

Notes: $* * *, * *, *$, significant at the 1,5 , and 10 percent levels. The table gives the coefficient, followed by the absolute value of the $t$-statistic. Note that each independent variable appeared in a separate regression. In each case, the dependent variable in the regression is Bankruptcy PC. The regression is two-stage least squares, and excludes Tokyo. In each regression, the independent variables included Attorneys PC (instrumented by Scriveners PC), GDP growth rate, Insolvency PC, Economic factor, Educational factor 1, Educational factor 2, and one of the variables above. 


\section{Bibliography:}

Acemoglu, Daron, Tristan Reed \& James A. Robinson. 2012. Chiefs: Elite Control of Civil Society and Economic Development in Sierra Leone. MIT Working Paper 13-01, SSRN 2211295.

Alesina, Alberto \& Eliana La Ferrara. 2000. Participation in Heterogeneous Communities. Q.J. Econ., xx: 847-904.

Annen, Kurt. 2003. Social Capital, Inclusive Networks, and Economic Performance. J. Econ. Behavior \& Org., 50: 449-63.

Aoki, Koji, ed. 1972. Taisho nomin sojo shiryo, nempyo [Material on Taisho Peasant Riots, Annual]. Tokyo: Gannando shoten, vols. 2 \& 3.

Berman, Sheri. 1997. Civil Society and the Collapse of the Weimar Republic. World Pol., 49: 401-29.

Bernstein, Lisa. 1992. Opting Out of the Legal System: Extralegal Contractual Relations in the Diamond Industry. J. Legal Stud., 21: 115-57.

Bourdieu, Pierre. 1985. The Forms of Capital. In J.G. Richardson, ed., Handbook of Theory and Research for the Sociology of Education. New York: Greenwood, pp. 241-58.

Bowles, Samuel \& Herbert Gintis. 2002. Social Capital and Community Governance. Econ. J., 112: F419-36.

Bryant, Taimie L. 1984. Marital Dissolution in Japan: Legal Obstacles and Their Impact. L. Japan, 17, 73.

Bunka cho. 2008. Shukyo nenkan, Heisei 20 nenban [Religion Annual, 2008]. Tokyo: K.K. Gyosei (pub. 2009).

CAA. See Consumer Affairs Agency.

Chambers, Simone \& Jeffrey Kopstein. 2001. Bad Civil Society. Pol. Theory, 29: 837-65.

Chusho kigyo cho. 2011. Chusho kigyo hakusho: fuzoku tokei shiryo [Small and Medium Sized Firm White Paper: Appendix Statistical Material], Tokyo: Keizai sangyo sho, Chusho kigyo cho. Available at: www.chusho.meti.go.jp/pamflet/hakusyo/h23/h23_1/110803Hakusyo_fuzokut okei_web.pdf

Coleman, James S. 1988. Social Capital in the Creation of Human Capital. Am. J. Soc., 94: S95-120.

Coleman, James S. 1990. Foundations of Social Theory. Cambridge: Harvard University Press.

Diamond Online. 2013. Kinkyu ankeeto [Urgent Opinion Poll]. Diamond Online, Sept. 25, 2013.

Durlauf, Steven N. 2002. On the Empirics of Social Capital. Econ. J., 112: F459-79.

Ellickson, Robert C. 1986. Of Coase and Cattle: Dispute Resolution Among Neibhbors in Shasta County. Stan. L. Rev., 38: 623-87. 
Ellickson, Robert C. 1991. Order without Law: How Neighbors Settle Disputes. Cambridge: Harvard University Press.

Ellickson, Robert C. 1998. Law and Economics Discovers Social Norms. J. Legal Stud., 27: 537.

Fukumi, Takao. 1928. Teito ni okeru baiin no kenkyu [Study of Prostitution in the Capital]. Tokyo: Hakubun kan,

Gekkyu saachi. 2009. Zenkoku kinzoku nensu rankingu [Job Tenure Rankings for the Country]. Available at http://www.ge9.biz/local/kinzoku.html.

Ginsburg, Tom, \& Glenn Hoetker. 2006. The Unreluctant Litigant? An Empirical Analysis of Japan's Turn to Litigation. J. Legal Stud., 35, 31-59.

Glaeser, Edward L., David I. Laibson, Jose A. Scheinkman \& Christine L. Soutter. 2000. Measuring Trust. Q.J. Econ., xx: 811-46.

Glaeser, Edward L., David Laibson \& Bruce Sacerdote. 2002. An Economic Approach to Social Capital. Econ. J., 112: F437-58.

Goldin, Claudia \& Lawrence F. Katz. 1999. Human Capital and Social Capital: The Rise of Secondary Schooling in America, 1910-1940. J. Interdisciplinary Hist., 29: 683-723.

Greif, Avner. 1993. Contract Enforceability and Economic Institutions in Early Trade: The Maghribi Traders. Am. Econ. Rev., 83: 525-48.

Grootaert, Christiaan \& Thierry van Bastelaer, eds. 2002. The Role of Social Capital in Development: An Empirical Assessment. Cambridge: Cambridge University Press.

Helliwell, John F. \& Robert D. Putnam. 2007. Education and Social Captal. E. Econ. J., 33: 1-19.

Homu sho. 2011. Hanzai hakusho [Crimes White Paper]. Tokyo: Homu sho.

Iwasaki, Masaki. 2004. Social Networks and Trust in Policies: Evidence from Contribution Evasion in Japan. Unpublished.

Japan Now. 2014. Todofuken betsu doro kotsu ho ihan kenkyo sokensu rankingu [Prefectural Ranking: Arrests for Traffic violations]. Available at: http://www.japan-now.com/article/236759603.html.

Katz, Avery. 1996. Taking Private Ordering Seriously. U. Pa. L. Rev., 144: 1745.

Kawagoe, Toshihiko. 1995. Sengo Nihon no nochi kaikaku [Land Reform in Postwar Japan]. Keizai kenkyu, 46: 249-59.

Keisatsu cho, ed. 1994. Keisatsu hakusho. Tokyo: Keisatsu cho.

Knack, Stephen \& Philip Keefer. 1997. Does Social Capital Have an Economic Payoff? A Cross-Country Investigation. Q.J. Econ., xx: 1251-88.

Knack, Stephen. 2002. Social Capital and the Quality of Government: Evidence from the States. Am. J. Pol. Sci., 46: 772-85.

Knack, Stephen. 2002b. Social Capital, Growth and Poverty: A Survey of CrossCountry Evidence. In Grootaert \& Bastelaer (2002). 
Kokusai kyoryoku jigyodan, ed. 1991. Kaigai iju tokei [Foreign Emigration Statistics]. Tokyo: Kokusai kyoryoku jigyodan.

Kokuzei cho. 2011. Kokuzeicho tokei nempo [National Tax Office Statistical Annual]. Available at: www.nta.go.jp/kohyo/tokei/kokuzeicho/h23/h23.pdf

Kokuzeicho. 2006. Dai 132 kai Kokuzeicho tokei nempo sho [132d National Tax Office Annual Report]. Tokyo: Kokuzei cho. Available at: http://www.nta.go.jp/kohyo/tokei/kokuzeicho/tokei_old.htm.

Kosei rodo sho. 2008. Jinko ninshin chusetsu kensu [Number of Abortions]. Available at: http://www.mhlw.go.jp/toukei/saikin/hw/eisei/07/toukei10.html.

Kosei rodo sho. 2010a. Jinko dotai tokei [Vital Statistics of Japan]. Available at: http://www.estat.go.jp/SG1/estat/GL08020103.do?_toGL08020103_\&listID=00000107110 4

Kosei rodo sho. 2010b. "Shussei ni kansuru tokei" no gaikyo [Outline of "Statistics Relating to Birth"]. Press release, Dec. 9, 2010.

Kosei rodo sho. 2013. Heisei 25 nen 5 gatsu sue genzai kokumin nenkin hokenryo no nofu ritsu [National Pension Insurance Payment Rate, as of Late May 2013]. Available at: http://www.mhlw.go.jp/stf/houdou/2r9852000003713eatt/2r9852000003717d.pdf.

Lieberman, Jethro K. 1983. The Litigious Society. Basic Books.

Matsumura, Toshihiro \& Marc Ryser. 1995. Revelation of Private Information about Unpaid Notes in the Trade Credit Bill System in Japan. J. Legal Stud., 24: 165-87.

Ministry of Health, Labour \& Welfare. 2012. Heisei 24 nendo no kokumin nenkin no kanyu, hokenryo nofu jokyo [Enrollment and Contribution Rates for National Pension, 2012]. Available at: http://www.mhlw.go.jp/topics/bukyoku/nenkin/nenkin/toukei/k-nenkin/

Monbu kagaku sho. 2005. Shakai kyoiku chosa [Survey of Social Education].

Monbu kagaku sho. 2008. Chiho kyokuikuhi chosa hokokusho [Report of Survey on Local Educational Expenses].

Monbusho, ed. 1926 Nihon teikoku monbusho nempo [Imperial Japanese Ministry of Education Annual]. Tokyo: Monbu sho.

Murray, Charles. 2012. Coming Apart: The State of White America, 1960-2010. New York: Crown Forum.

NHK hoso bunka kenkyujo. 2012. Jushinryo no todofukenbetsu setai shiharai ritsu [Prefecture-Level Payment Rates of NHK Reception Fee]. Available at: http://www.nhk.or.jp/bunken/summary/research/focus/523.html.

NHK mikeiyaku setai demo jushinryo, shiharai meijiru hanketsu[Even NonContracted households must pay Broadcast Fee, Orders Court.] Yomiuri Online, 6/28/2013. http://www.yomiuri.co.jp/entertainment/news2/20130628OYT8T00572.htm 
Naikaku fu. 2013. Kokumin keizai keisan, 22 nendo [Prefectural Residents Economic Calculations, 2010]. Available at: www.esri.cao.go.jp/jp/sna/sonota/kenmin/kenmin_ top.html

Naikaku tokei kyoku, ed. 1926. Jinko dotai tokei, showa 1 nen [Vital Statistics, 1926]. Tokyo: Tokyo tokei kyokai.

Nenshu rabo. 2012. fukenbetsu nenshu rankingu [Ranking of Annual Income, by Prefecture]. Available at http://nensyu-labo.com/2nd_ken_ranking.htm (for 2008 ime figures).

Nihon ABC Kyokai. 2011. Shinbun hakkosha repoto fukyu ritsu [Diffusion Rate, Newspaper Publisher Report], July-Dec., 2011. Available at: adv.yomiuri.co.jp/yomiuri/busu/busu01b.html.

Nihon bengoshi rengo kai. 2011. Bengoshi hakusho [Attorney White Paper]. Tokyo: Nihon bengoshi rengo kai.

Nihon nenkin kiko. 2013. Japanese National Pension System, Available at: http://www.nenkin.go.jp/n/www/share/pdf/existing/english/pdf/1.pdf

Nihon shiho shoshi rengo kai. 2012. Nihon shiho shoshi rengo kai [Japan Federation of Judicial Scriveners] (home page). Available at: http://www.shihoshoshi.or.jp/association/shiho_shoshi_list.php.

Noble, Gregory W. 2014. The Consumption Tax Increase and Japanese Governance. Unpublished MS.

Norin sho. 1925. Norin sho tokei hyo [The Ministry of Agriculture \& Forestry Statistics]. Tokyo: Norin sho.

Onishi, Norimitsu. 2004. Japan Opposition Leader Quits in Pension Payment Scandal, N.Y. Times, May 11, 2004.

Ostrom, Elinor. 1998. A Behavioral Approach to the Rational Choice Theory of Collective Action. Am. Pol. Sci. Rev., 91: 1-22.

Paxton, Pamela. 1999. Is Social Capital Declining in the United States? A Multiple Indicator Assessment. Am. J. Soc., 105: 88-127.

Portes, Alejandro. 1998. Social Capital: Its Origins and Applications in Modern Sociology. Ann. Rev. Sociol., 24: 1-24.

Posner, Eric A. 1996. The Regulation of Groups: The Influence of Legal and Nonlegal Sanctions on Collective Action. U. Chi. L. Rev. 63: 133.

Posner, Eric A. 1998. Symbols, Signals, and Social Norms in Politics and the Law. J. Legal Stud., 27: 765-97.

Posner, Eric A. 2000. Law and Social Norms: The Case of Tax Compliance. Virg. L. Rev., 86: 1781-1819.

Posner, Eric A. 2002. Law and Social Norms. Cambridge: Harvard University Press.

Posner, Richard A. 1973. An Economic Approach to Legal Procedure and Judicial Administration. J. Legal Stud., 2, 399.

Posner, Richard A. 1997. Social Norms and the Law: An Economic approach. Am. Econ. Rev., 87, 365-369 (P\&P). 
Posner, Richard A. 1998. Social Norms, Social Meaning, and Economic Analysis of Law: A Comment. J. Legal Stud., 27: 553-565.

Posner, Richard A. \& Eric B. Rasmusen. 1999. Creating and Enforcing Norms, with Special Reference to Sanctions. Int'l Rev. L. \& Econ., 19, 369-382.

Putnam, Robert D. 1995. Bowling Alone: America's Declining Social Capital. J. Democracy, Jan. 1995, 65-78.

Putnam, Robert D. 2000. Bowling Alone: The Collapse and Revival of American Community. New York: Simon \& Schuster.

Putnam, Robert D. \& Kristin A. Goss. 2002. Introduction. Robert D. Putnam, ed. Democracies in Flux. Oxford: Oxford University Press.

Ramseyer, J. Mark. 1991. Legal Rules in Repeated Deals: Banking in the Shadow of Defection in Japan. J. Legal Stud., 20: 91.

Ramseyer, J. Mark. 1994. The Puzzling (In)dependence of Courts: A Comparative Approach. J. Legal Stud., 23: 721.

Ramseyer, J. Mark. 2014. Litigation and Social Capital: Divorces and Traffic Accidents in Japan. J. Empirical Legal Stud., 11: 39-73.

Ramseyer, J. Mark \& Eric B. Rasmusen. 2001. Why Are Japanese Judges so Conservative in Politically Charged Cases? Am. Pol. Sci. Rev. 95: 331.

Ramseyer, J. Mark \& Eric B. Rasmusen. 2003. Measuring Judicial Independence: The Political Economy of Judging in Japan. Chicago: University of Chicago Press.

Rice, Tom W. \& Alexander F. Sumberg. 1997. Civic Culture and Government Performance in the American States. Publius, 27: 99-114.

Riley, Dylan. 2005. Civic Associations and Authoritarian Regimes in Interwar Europe: Italy and Spain in Comparative Perspective. Am. Soc. Rev., 70: 288310.

Sabatini, Fabio. 2009. Social Capital as Social Networks: A New Framework for Measurement and an Empirical Analysis of Its Determinants and Consequences. J. Socio-Econ., 38: 429-42.

Saegert, Susan \& Gary Winkel. 2004. Crime, Social Capital, and Community Participation. Am. J. Community Psychology, 34: 219-33.

Saiko saibansho, ed. 1994. Shiho tokei nempo: 1 Minji, gyosei hen [Annual Report of Judicial Statistics: 1 Civil \& Administrative Cases]. Tokyo: Hoso kai.

Satyanath, Shanker, Nico Voiglaender \& Hans-Joachim Voth. 2013. Bowling for Fascism: Social Capital and the Rise of the Nazi Party in Weimar Germany, 1919-1933. NBER Working Paper 19201, July 2013.

Shohisha sho. 2012. Todoufukenbetsu no shihoshoshi su tno kikaku hyo [Comparative Table of Judicial Scrivener and Attorney populations, by Prefecture]. Available at: www.caa.go.jp/seikatsu/shingikai2/kako/spc16/houkoku_c/spc16-houkoku_cref_29.html.

Skinner, Jonathan \& Douglas Staiger. 2007. Technology Adoption from Hybrid Corn to Beta-Blockers. In E. Berndt \& C.M. Hulten, eds., Hard-to-Measure 
Goods and Services: Essays in Honor of Zvi Griliches, pp. 545-70. Chicago: University of Chicago Press.

Somu sho. 2003. Senkyo kanren shiryo [Materials Related to Elections]. Available at: http://www.soumu.go.jp/senkyo/senkyo_s/data/shugiin44/index.html.

Somu sho. 2004. Zenkoku shohi jittai chosa [Survey of National Consumption]. Tokyo: Somusho.

Somu sho. 2006. Shakai seikatsu kihon chosa [Basic Survey of Social Life]. Available at: http://www.stat.go.jp/data/shakai/2011/trivia/index.htm\#table3

Somu sho. 2012. Rodoryoku chosa [Survey of Labor Force]. Available at: http://www.stat.go.jp/data/roudou/pref/index.htm (for unemp)

Somu sho. 2013. Nihon tokei nenkan [Japan Statistical Annual]. Available at: http://www.stat.go.jp/data/nenkan/12.htm.

Stata. 2005. Stata Multivariate Statistics Reference Manual: Release 9. College Station: Stata Press.

Stolle, Dietlind \& Thomas R. Rochon. 1998. Are All Associations Alike? Member Diversity, Associational Type, and the Creation of Social Capital. Am. Behavioral Scientist, 42: 47-65.

Toba, Ken. 2005. Nihonjin no heikinchi [Average Values for Japanese]. Tokyo: Seikatsu joho sentaa.

Todo-ran, 2013f. [Title.\} Available at: http://todo-ran.com/t/kiji/12125.

Todo-ran. 2013a. Gaikokusha fukyu ritsu [Foreign Car Diffusion Rate]. Available at: http://todo-ran.com/t/kiji/13749.

Todo-ran. 2013b. Zenkoku gakuryoku tesuto [National Scholastic Test]. Available at: http://todo-ran.com/t/kiji/12090.

Todo-ran. 2013c. Zenkoku gakuryoku tesuto chugakusei seito ritsu [Percentage Right Answer on Middle-School National Scholastic Test]. Available at: http://todo-ran.com/t/kiji/16236.

Todo-ran. 2013d. Chugakko futoko seito su [Number of Middle-School Students Missing School]. Available at: http://todo-ran.com/t/kiji/13836.

Todo-ran. 2013e. [Title.] Available at: http://todo-ran.com/t/kiji/11541.

Tokyo shoko risaachi. 2013. Website available at: http://www.tsrnet.co.jp/news/status/fiscal_year/ 1226755_1635.html 